\title{
EVALUATING LOSSES ASSOCIATED WITH AFRICAN SWINE FEVER IN THE PEOPLE'S REPUBLIC OF CHINA AND NEIGHBORING COUNTRIES
}

Thomas R. D. Weaver and Najibullah Habib

NO. 27

October 2020

\author{
ADB EAST ASIA \\ WORKING PAPER SERIES
}





\section{ADB East Asia Working Paper Series}

\section{Evaluating Losses Associated with African Swine Fever in the People's Republic of China and Neighboring Countries}

Thomas R. D. Weaver and Najibullah Habib

No. 27 | October 2020
Thomas R.D. Weaver is a consultant for the Asian Development Bank (ADB). He provides technical, economic, and management advice on agriculture and livestock production, health and supply to governments, development agencies, research institutes, and private sector interests. Weaver received his Ph.D. in epidemiology from the Faculty of Veterinary and Agricultural Sciences, University of Melbourne, Australia. He also holds an MA from the Institute of Development Studies, United Kingdom, and a BA from University College London, United Kingdom.

Najibullah Habib is a health specialist working in ADB's East Asia Urban and Social Sectors Division. $\mathrm{He}$ has more than 20 years of international experience in international public health and development with global institutions. He is a physician with a doctorate degree in Public Health. 
(C) 2020 Asian Development Bank 6 ADB Avenue, Mandaluyong City, 1550 Metro Manila, Philippines

Tel +632 8632 4444; Fax +63286362444

www.adb.org

Some rights reserved. Published in 2020.

Printed in the Philippines

Publication Stock No. WPS200263-2

DOI: http://dx.doi.org/10.22617/WPS200263-2

The views expressed in this publication are those of the authors and do not necessarily reflect the views and policies of the Asian Development Bank (ADB) or its Board of Governors or the governments they represent.

ADB does not guarantee the accuracy of the data included in this publication and accepts no responsibility for any consequence of their use. The mention of specific companies or products of manufacturers does not imply that they are endorsed or recommended by ADB in preference to others of a similar nature that are not mentioned.

By making any designation of or reference to a particular territory or geographic area, or by using the term "country" in this document, $A D B$ does not intend to make any judgments as to the legal or other status of any territory or area.

This work is available under the Creative Commons Attribution 3.0 IGO license (CC BY 3.0 IGO)

https://creativecommons.org/licenses/by/3.0/igo/. By using the content of this publication, you agree to be bound by the terms of this license. For attribution, translations, adaptations, and permissions, please read the provisions and terms of use at https://www.adb.org/terms-use\#openaccess.

This CC license does not apply to non-ADB copyright materials in this publication. If the material is attributed to another source, please contact the copyright owner or publisher of that source for permission to reproduce it. $\mathrm{ADB}$ cannot be held liable for any claims that arise as a result of your use of the material.

Please contact pubsmarketing@adb.org if you have questions or comments with respect to content, or if you wish to obtain copyright permission for your intended use that does not fall within these terms, or for permission to use the ADB logo.

Corrigenda to ADB publications may be found at http://www.adb.org/publications/corrigenda.

Notes:

In this publication, "\$" refers to United States dollars and "CNY" to yuan.

ADB recognizes "China" as the People's Republic of China, and "Vietnam" as Viet Nam.

The ADB East Asia Working Paper Series is a forum for stimulating discussion and eliciting feedback on ongoing and recently completed research and policy studies undertaken by the East Asia Department of the Asian Development Bank (ADB) staff, consultants, or resource persons. The series deals with key economic and development problems, as well as conceptual, analytical, or methodological issues relating to project/program economic analysis, and statistical data and measurement. The series aims to enhance the knowledge on Asia's development and policy challenges; strengthen analytical rigor and quality of ADB's country partnership strategies, and its subregional and country operations; and improve the quality and availability of statistical data and development indicators for monitoring development effectiveness.

The ADB East Asia Working Paper Series is a quick-disseminating, informal publication whose titles could subsequently be revised for publication as articles in professional journals or chapters in books. The series is maintained by the East Asia Department. 


\section{CONTENTS}

TABLES AND FIGURES Iv

ACKNOWLEDGMENTS $\quad$ v

ABBREVIATIONS vi vi

$\begin{array}{lcl}\text { ABSTRACT vii } & \text { vi }\end{array}$

$\begin{array}{lll}\text { I. INTRODUCTION } & 1\end{array}$

$\begin{array}{lr}\text { II. } & \text { BACKGROUND }\end{array}$

$\begin{array}{ll}\text { III. METHODOLOGY } & 3\end{array}$

A. Caveats and Assumptions 4

$\begin{array}{llr}\text { IV. } & \text { RESULTS }\end{array}$

$\begin{array}{ll}\text { V. DISCUSSION } & 11\end{array}$

$\begin{array}{ll}\text { VI. RECOMMENDATIONS } & 14\end{array}$

A. Strengthening Capacity to Prevent and Control Animal Diseases $\quad 14$

B. Investment Scenarios for Interventions 16

$\begin{array}{llr}\text { VII. } & \text { CONCLUSIONS } & 17\end{array}$

APPENDIXES

1. Methods Employed to Estimate Direct Costs of African Swine Fever 18

2. Parameters Used in the Livestock Development Planning System, 22

Version 2 Herd Dynamic Model

3. Supplementary Data: Initial Costs of Disease in the People's 24

Republic of China and the Greater Mekong Subregion

4. Critical Transboundary Animal Diseases, Foodborne Pathogens, 26 and Non-Foodborne Zoonoses 


\section{TABLES AND FIGURES}

\section{TABLES}

1 Estimated Direct Costs of African Swine Fever on Production by Country 6

A1.1 Pig Price Data Used in Cross-country Analyses 19

A1.2 Pig Price Data Used in within the People's Republic of China Analyses 20

A2 Production Parameters Used in the Food and Agriculture 22

Organization of the United Nations Livestock Development Planning

System, Version 2 Herd Dynamic Model

A3 Initial Cost of Disease Parameters and Results 24

A4 Examples of Terrestrial Animal Production Associated Hazards 26

in the People's Republic of China and the Greater Mekong Subregion

\section{FIGURES}

1 Herd Numbers and Approximate Demographics by

Production System and Production Stage Prior to the African Swine

Fever Epidemic by Production System and Production Stage

2 Estimated Direct Costs to Production by Country 6

3 Estimated Initial Costs of Deaths, Morbidity, and Culls of the 7

African Swine Fever Outbreak by Production System and Country

4 Estimated Initial Costs of Deaths, Morbidity, and Culls of the 8

African Swine Fever Outbreak in the People's Republic of China by Region and Production Stage

5 Estimated Initial Costs of Deaths, Morbidity and Culls of the

African Swine Fever Outbreak in the People's Republic of China by Province and Production Stage

6 Estimated Direct Costs of Hypothetical African Swine Fever Control Scenarios Estimated Direct Costs to Production if the Disease had been Controlled in Liaoning Province 


\section{ACKNOWLEDGMENTS}

We would like to acknowledge the following persons who provided valuable insights and inputs to the report: Dominic Smith, senior research fellow, School of Agriculture and Food Sciences, University of Queensland; Damian Tago Pacheco, regional animal health economist, Emergency Center for Transboundary Animal Diseases, Food and Agriculture Organization of the United Nations, Regional Office for Asia and the Pacific; Jonathan Tuke, senior lecturer in statistics, School of Mathematical Sciences, University of Adelaide; John Weaver, veterinarian and veterinary epidemiologist; Takashi Yamano, senior economist, Asian Development Bank; and Shingo Kimura, senior natural resources and agriculture specialist, Asian Development Bank. We also wish to thank James Lynch, director general of the East Asia Department of the Asian Development Bank, M. Teresa Kho, deputy director general of the East Asia Department of the Asian Development Bank, and Sangay Penjor, director of the

Urban and Social Sectors Division, East Asia Department of the Asian Development Bank for their kind encouragement and support for this publication. 


\section{ABBREVIATIONS}

$\begin{array}{ll}\text { ADB } & \text { Asian Development Bank } \\ \text { ASF } & \text { African swine fever } \\ \text { FAO } & \text { Food and Agriculture Organization of the United Nations } \\ \text { FAOSTAT } & \text { Food and Agriculture Organization Corporate Statistical Database } \\ \text { FMD } & \text { foot-and-mouth disease } \\ \text { GHG } & \text { greenhouse gas } \\ \text { GMS } & \text { Greater Mekong Subregion } \\ \text { Lao PDR } & \text { Lao People's Democratic Republic } \\ \text { PRC } & \text { People's Republic of China } \\ \text { OIE } & \text { Office International des Epizooties (World Organisation for Animal Health) } \\ \text { SPS } & \text { sanitary and phytosanitary standards } \\ \text { TAD } & \text { transboundary animal disease } \\ \text { USDA } & \text { United States Department of Agriculture } \\ \text { WHO } & \text { World Health Organization }\end{array}$




\begin{abstract}
The introduction and spread of African swine fever (ASF) in the People's Republic of China (PRC) and through many areas in Southeast Asia underscores the importance of animal diseases in economics and trade in the region. The PRC raises approximately $50 \%$ of the world's pigs; an industry worth over $\$ 128$ billion. The industry is an essential component of the national economy and source of livelihood and food security for much of the population. Current estimates indicate that at least $25 \%$ and perhaps as much as 55\% of the PRC's national herd has been lost to the disease and culling since it was first reported. Its impacts on livelihoods and food security in neighboring countries are equally disastrous.

To assist policymakers in assessing the scale of the impact, this paper employed a deterministic analysis and approach to estimating the direct costs of the disease. The results indicate direct costs of ASF on the PRC and neighboring countries of $\$ 55$ billion- $\$ 130$ billion. Of this, $\$ 28$ billion- $\$ 46$ billion were attributed to initial losses to disease and culling, $\$ 4$ billion- $\$ 7$ billion to the cost of replacement breeding animals, and $\$ 23$ billion- $\$ 77$ billion in revenue forgone. However, if the disease was successfully contained in Liaoning Province, initial losses would have been $\$ 3.6$ billion- $\$ 5.2$ billion. The burden of the disease is falling disproportionately on smallholders-for whom pig raising is often a critical livelihood mechanism and safety net-in absolute terms and on a per pig basis, thereby threatening increases in poverty, vulnerability, and food insecurity. Exacerbating this, the supply side shock is driving up pork, other food, and general prices for consumers. The effects of the disease on human health security, trade, the climate, climate change resilience, and local environments are also substantial.

The ASF epidemic highlights the massive economic and human costs associated with it and the potential costs of other animal disease outbreaks in the future. There is an urgent need for regional investment in animal health system infrastructure, capacity building, and policy to reduce the likelihood and costs of current and future animal diseases and zoonoses. Further research is needed to better inform national and regional decision making, and direct investments in animal and zoonotic disease prevention, monitoring, and control.
\end{abstract}





\section{INTRODUCTION}

1. The economic burden of animal diseases is recognized to be substantial. Disease characteristics, the susceptibility of animal populations and environmental factors determine rates of infection, mortality, and impacts on productivity in animals and may directly, in the case of zoonoses, ${ }^{1}$ affect human health (Rushton et al. 2018). Meanwhile, loss of livestock, trade, decreased market value, food insecurity, environmental impacts, and efforts to respond to animal diseases all come at considerable costs to livelihoods and both public and private sector interests (Barratt et al. 2019). Endemic and emerging transboundary animal diseases (TADs) threaten livestock producers in Asia, hampering livestock productivity, causing market disruptions, and inhibiting formal trade production animals and products. Knight-Jones and Rushton (2013) estimated the global costs of foot-and-mouth disease (FMD) alone to be $\$ 21$ billion.

2. An estimated $75 \%$ of emerging infectious diseases are zoonotic and some $61 \%$ of human pathogens are zoonoses (Jones et al. 2008 and World Health Organization [WHO] 2006), leading to high costs in healthcare, lost labor, lost tourism, and reduced export market access. The World Bank (2017) estimated that East Asia and the Pacific have the highest vulnerability to economic losses from pandemics, estimating annual losses of $\$ 200$ billion, which equates to $0.9 \%$ of the region's gross domestic product. The global direct costs of zoonotic diseases, specifically, has been estimated at more than $\$ 20$ billion and indirect losses at over $\$ 200$ billion to affected economies (Barratt et al. 2019 and World Bank 2010). In addition, foodborne pathogens and rising antimicrobial resistance (AMR) threaten human health and are often integrally linked to animal production and products. Worldwide, more than 600 million cases of foodborne illness are estimated to occur each year, costing human health over 5.5 million disability-adjusted life years and causing over 400,000 deaths (Havelaar et al. 2015). Resistant pathogens currently cause an estimated 700,000 deaths per year globally, which, if left unchecked, is expected to reach 10 million deaths and a global cost $\$ 100$ trillion by 2050 (O'Neill 2014). Overuse and inappropriate use of antimicrobials in animal production is a key driver of AMR. The current high use of antimicrobials in animal production in Asia is expected to grow dramatically in the coming years with further intensification of livestock industries (Van Boeckel et al. 2015). Control of TADs is essential to reduce current and future reliance on antimicrobials, particularly in light of the likely heightened risk of disease emergence and spread due to the effects of climate change.

3. The introduction and spread of African swine fever (ASF) in the People's Republic of China (PRC) in August 2018 and subsequent spread through much of Asia had highlighted the importance of animal diseases. The PRC alone raises approximately $50 \%$ of the world's pigs; an industry worth over $\$ 128$ billion. The industry is an essential component of the national economy and a critical source of livelihood and food security for much of the population (Gale et al. 2019). Current estimates are that at least 25\% and perhaps as much as 55\% of the PRC national pig herd has been lost to the disease and culling since it was first reported (World Grain 2019 and Mackenzie 2019). It will take years of herd-rebuilding for the industry to fully recover and with the disease now effectively endemic, challenges will remain at least until such time as an effective vaccine becomes available (McCracken et al. 2019). Although the scale of the PRC pig production dwarfs the impacts of ASF in neighboring countries, the impacts on livelihoods and food security will be equally catastrophic. For example, in Viet Nam, which has a similarly high per

World Health Organization (WHO) defines a zoonosis as "any disease or infection that is naturally transmissible from vertebrate animals to humans. Animals thus play an essential role in maintaining zoonotic infections in nature. Zoonoses may be bacterial, viral, or parasitic, or may involve unconventional agents. As well as being a public health problem, many of the major zoonotic diseases prevent the efficient production of food of animal origin and create obstacles to international trade in animal products." WHO. Health Topics. Zoonoses. http://origin.who.int/topics/zoonoses/en/. 
capita pig production and pork consumption, the pig population has decreased by as much as $40 \%$ in the worst affected areas and at the time of writing, over five million pigs had been culled in response to the disease (Food and Agriculture Organization of the United Nations [FAO] 2019).

4. The true burden of the disease is unlikely to ever be fully accounted for. The paucity of accurate production data, likelihood of misdiagnosis and underreporting, political incentives, complexity of assessing indirect costs and the difficulties of accounting for impacts on human health and nutrition, loss of livelihoods, and less tangible impacts such as effects on social capital, make accurate assessment problematic. However, it is critical to policymaking and the provision of resources to mitigate risk and control diseases that attempts are made to assess the scale of the impact. Initial estimates are presented here based on the use of simple deterministic methods in a number of scenarios. This paper reports on preliminary analysis of the potential economic burden of direct costs of ASF on the PRC and neighboring countries of the Greater Mekong Subregion² (GMS) which had, at the time of writing, confirmed the presence of the disease. The results are discussed in relation to the more complex indirect impacts of the disease. This paper also touches upon other important endemic and emerging diseases that affect, or could affect, animal production, trade, economic development, and human health in the region. Investments necessary to reduce the burden of future disease outbreaks in animal production are identified in this paper and an urgent call for further research in this area is issued.

\section{BACKGROUND}

5. ASF is caused by the ASF virus, a highly resilient DNA virus with no effective vaccine at present (Gallardo et al., 2009 and Halasa et al. 2018). The highly virulent strain of Genotype Il currently circulating in Asia has an estimated case fatality rate of 90\%-95\% in pigs (Gallardo et al. 2017 and Chenais et al. 2019). ASF typically presents with sudden death or, with less virulent strains, a high fever, generalized reddening of the skin, listlessness, congestion, and generalized hemorrhage of the lymph nodes and internal organs (Zhou et al. 2018 and World Organisation for Animal Health [OIE] 2019a). The virus may be transmitted via direct animal contact, through feeding of contaminated meat or products, and via vectors ${ }^{3}$ (Ornithodoros soft ticks) or fomites. ${ }^{4}$ Efforts to control this devastating disease are severely hampered by the lack of an effective vaccine and subsequently rely on disease reporting, culling, biosecurity, market closures, and movement bans and surveillance efforts to limit transmission, which, of course, come at considerable cost.

6. The first confirmed outbreak of ASF in Asia was reported in a farm in Shenyang City, Liaoning Province in August 2018 (Ge et al. 2018, Zhou et al. 2018, and Li and Tian 2018). All 400 pigs at the farm died within 1 month of the first clinical signs, and the farm, like many others subsequently, was abandoned (Zhou et al. 2018). The virus was introduced to the PRC from eastern Europe seemingly

\footnotetext{
GMS countries include Cambodia, Lao People's Democratic Republic (Lao PDR), Myanmar, the PRC, Thailand, and Viet Nam. This study does not include Thailand, however for the purposes of brevity, this paper will refer to the countries as GMS.

3 WHO define vectors as: "living organisms that can transmit infectious diseases between humans or from animals to humans. Many of these vectors are bloodsucking insects, which ingest disease-producing microorganisms during a blood meal from an infected host (human or animal) and later inject it into a new host during their subsequent blood meal. Mosquitoes are the best-known disease vector. Others include ticks, flies, sandflies, fleas, triatomine bugs and some freshwater aquatic snails." WHO. TDR. Diseases and Topics. Vectors. https://www.who.int/tdr/diseases-topics/vectors/en/.

4 A fomite is an inanimate object or substance that may be contaminated with infectious organisms and serve in their transmission between individual hosts.
} 
through anthropogenic factors, in all likelihood via contaminated meat or pork products incorporated into swill feed. Since the first outbreak, over 160 ASF outbreaks have been confirmed in 32 provinces, autonomous regions, municipalities, and Special Administrative Regions in the PRC (Food and Agriculture Organization of the United Nations [FAO] 2019). The disease has subsequently spread to Viet Nam, Cambodia, the Democratic People's Republic of Korea, the Lao PDR, Myanmar, the Philippines, the Republic of Korea, and, most recently, Timor-Leste. It is likely that it will spread further in Southeast Asia, to Micronesia and Polynesia, and beyond.

7. The responses to ASF had been severe by necessity. Widespread culling had been implemented in all affected countries; generally culling of all animals on farms with confirmed cases, testing of neighboring farms and farms with a direct connection to infected herds. Movement bans and market closures had been enacted. Heightened monitoring had been implemented to the degree feasible. Compensation systems had been established to varying degrees. Extensive awareness raising campaigns had been developed, encouraging reporting of any suspicious disease and improved biosecurity measures.

\section{METHODOLOGY}

8. This analysis sought to assess the scale of direct production costs associated with the ASF epidemic on the PRC and neighboring GMS countries in which the disease had been confirmed by

October 2019. The direct costs were assessed in terms of initial stock losses due to the disease and culling and loss of value due to morbidity, the costs of replacing lost breeding animals to return supply to levels prior to the outbreak, and the revenue forgone during the period of herd rebuilding. Although this is not an exhaustive assessment of direct costs, it does constitute the major direct costs in the case of ASF, with the exception of the impact of the feed industry. This analysis does not attempt to quantify the indirect costs of the disease-such as the costs of control efforts, economic loss incurred in other affected commodity markets, loss of livelihoods, reduced household spending-though the potential impacts are considered in the discussion section (Barratt et al. 2019). Further research is undoubtedly needed.

9. A deterministic approach was used to assess the direct costs of the ASF epidemic. The analyses were carried out in the statistical software R and using the FAO Livestock Development Planning System, version 2 herd dynamic model run in Excel (Lalonde and Sukigara 1997, R Core Team 2019). Pig population data was sourced from the Food and Agriculture Organization Corporate Statistical Database (FAOSTAT) and figures from 2017, prior to the ASF outbreak, or the most recent available prior to that year were used. Herd demographics (Figure 1) were estimated on the basis of the literature and expert consultation (Smith et al. 2019 and Deka et al. 2014). Disease and production parameters were derived from literature review and discussion with experts in the field and corroborated through media reports. Sensitivity analyses were conducted using minimum and maximum values for disease characteristics and reported and/or estimated production figures. Total direct losses were calculated for $30 \%$ and $50 \%$ infection rates, as had been reported for the PRC (World Grain 2019 and Mackenzie 2019). A conservative mortality rate of $90 \%$ was used, which had been reported for the strain (II) currently circulating in the region by Chenais et al. (2019), although up to $95 \%$ case fatality had been reported for this strain elsewhere (Gallardo et al. 2017). National pork demand and consumption figures were obtained from various sources including the United States Department of Agriculture (USDA) and online reports. Hog price data used were average reported prices for pigs per kilogram liveweight (prices for prewean piglets, weaner-grower-finishers, and sows) using figures from as close to the time of the outbreak as possible (USDA 2016, USDA 2019, FAOSTAT 2019, Zhang 2019, and Nga et al. 2015). The methods used are further detailed in Appendix 1 and the parameters used are detailed in Appendixes 2 and 3. 


\section{Figure 1: Herd Numbers and Approximate Demographics Prior to the African Swine Fever Epidemic by Production System and Production Stage}
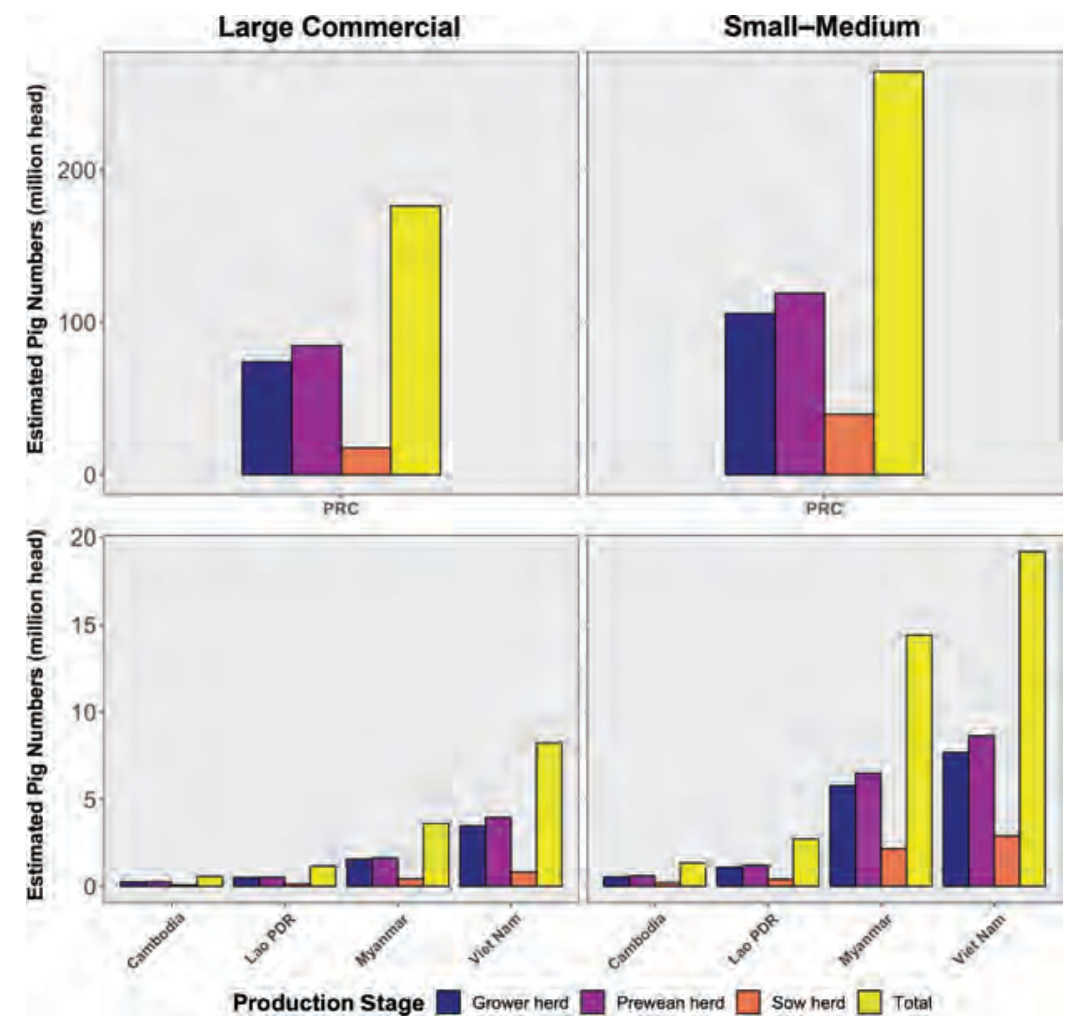

Lao PDR = Lao People's Democratic Republic, PRC = People's Republic of China.

Note: production system = large intensive commercial vs small-medium scale; production stages = sows, prewean, weanergrower-finisher accessed 29 October 2019.

Source: Asian Development Bank; Food and Agriculture Organization Corporate Statistical Database. 2019. ASF Situation in Asia Update. http://www.fao.org/ag/againfo/programmes/en/empres/ASF/Situation_update.html (accessed 29 October 2019); National Bureau of Statistics of China. 2018. National Data. http://data.stats.gov.cn/english/easyquery.htm? $\mathrm{cn}=\mathrm{E} 0103 \& \mathrm{f}=912$ (accessed 7 November 2019).

\section{A. Caveats and Assumptions}

10. As indicated, this paper presents a preliminary analysis and there are a number of important caveats and assumptions to consider. FAO (2016) highlights the paucity of production and price data as a major challenge in assessing the impacts of animal diseases, this is certainly the case in this instance (Phipps 2019). The figures used are the most recent available from national census data (obtained from FAOSTAT) and validated with reference to other studies, but their accuracy is uncertain given the nature of pig farming in the region and high numbers of frequently unregistered smallholders and estimates of pig inventories and losses in the PRC vary widely. Other factors beyond ASF had affected pig production, such as the new environmental protection law, which had led to the closure of many small pig breeding farms and forced many large-scale farms to relocate to the northwest (Zhang 2019).

11. The costs to the feed industry were not assessed, which will be substantial. This analysis does not attempt to quantify indirect costs of ASF, which are undoubtedly extremely high but are very challenging to estimate given the high complexity and data-related issues. This was deemed beyond the scope of this preliminary analysis but certainly warrants further investigation. 
12. In terms of disease characteristics, a simple deterministic approach was adopted. Key parameters were obtained from literature and through expert consultation. Sensitivity analysis was conducted and "lower" and "higher" estimates provided based on two scenarios. This deterministic approach radically simplifies the epidemiological characteristics of the disease's progression for the purposes of assessing short-term direct costs on production. We assume farms have an equal chance of being infected, i.e., there are no clustering effects. This was considered a reasonable assumption at the beginning of the outbreak due to the prevalence of swill feeding among the (formerly) ubiquitous smallholder subsector. However, now that large commercial suppliers, in particular, have strengthened biosecurity measures considerably, this is likely no longer valid. No attempt was made to account for intraherd transmission rates, or to use more complex transition models of disease spread or of different modes of transmission, such as considering potential effects of farm input supply, product and/or live animal and/or vector and/ or fomite transmission pathways, to the role of wild pigs, etc., in clustering. Due to the issues with data and wide-ranging assumptions, this study did not account for uncertainty in the analyses since this would potentially be misleading by portraying the results as more robust than they in fact are; given the stakes at hand, transparency of methods is paramount. Further epidemiological, economic, and sociological research in this area is crucial and necessary.

13. Pig prices used in this study were national averages for the PRC for 2017 , the year prior to the ASF outbreak. The PRC pig prices were used because regional pig prices have been highly volatile relative to other meat and animal prices in recent years and reliable price data was difficult to obtain for all of the study countries. However, local prices within the PRC and the region undoubtedly vary considerably and there are certainly seasonal price trends. It was also assumed that pig prices would remain stable during and in the aftermath of the epidemic, therefore, this analysis underestimates the costs of replacement of breeding stock and revenue forgone. Demand for replacement stock is likely to be heightened although there are less farms, while supply has been dramatically reduced. This is easily observed in the PRC and global pig and pork prices.

14. Finally, the value of pigs that succumbed to ASF or were culled was assumed to be zero. However, it is likely that pork from some of these pigs had been consumed or sold. Given that there was no way to reliably estimate the volume or value of this, it was not included in the analysis.

\section{RESULTS}

15. Costs of direct losses in the PRC and neighboring GMS countries in which ASF had been confirmed were estimated to be between $\$ 55$ billion- $\$ 130$ billion (Table 1 and Figure 2 ). To provide an idea of the scale of these losses, the United States pork industry is estimated to contribute approximately $\$ 40$ billion to the country's gross domestic product (National Pork Producers Council no date). Of these costs, $\$ 28$ billion- $\$ 46$ billion were attributed to initial losses to disease and culling. Assuming losses of $30 \%-50 \%$ of the national breeder herd, to restore the breeder herd to the levels necessary to meet the estimated demand pre-ASF of 55 million tons of pork per year requires some 11 million-12 million heads to be diverted from the market into the breeding herd (approximately 10.5-22.0 million gilts and 0.4 million-0.8 million boars) (Patton and Gu 2019 and USDA 2019). At an average price of approximately $\$ 175$ per head for finished hogs (average 70 kilograms [kg] finished weight for smallholders and $90 \mathrm{~kg}$ for intensive producers [Appendix 1]) diverted to replacement gilts and boars, the estimated direct cost of replacements is $\$ 4$ billion- $\$ 7$ billion. In addition, the loss of litters over a minimum of 1 year, or approximately two farrowings, at an average 20 pigs sold per sow per year is an additional $\$ 23$ billion$\$ 77$ billion in revenue forgone, calculated on the basis of approximate average profit per finished pig averaging the PRC prices before (August 2018) and 1 year after (August 2019) (Patton 2019). 
Table 1: Estimated Direct Costs of African Swine Fever on Production by Country

\begin{tabular}{|c|c|c|c|c|c|c|c|c|}
\hline \multirow[b]{2}{*}{ Country } & \multicolumn{2}{|c|}{$\begin{array}{c}\text { Initial Stock } \\
\text { Losses } \\
(\$ \text { million })\end{array}$} & \multicolumn{2}{|c|}{$\begin{array}{c}\text { Replacement } \\
\text { Breeders } \\
(\$ \text { million })\end{array}$} & \multicolumn{2}{|c|}{$\begin{array}{l}\text { Revenue } \\
\text { Forgone } \\
\text { (\$ million) }\end{array}$} & \multicolumn{2}{|c|}{$\begin{array}{c}\text { Total } \\
(\$ \text { million })\end{array}$} \\
\hline & Lower & Upper & Lower & Upper & Lower & Upper & Lower & Upper \\
\hline PRC & 24,956 & 41,594 & 3,851 & 6,543 & 21,486 & 72,981 & 50,293 & 121,118 \\
\hline Cambodia & 108 & 180 & 8 & 14 & 44 & 152 & 160 & 346 \\
\hline Lao PDR & 217 & 361 & 5 & 8 & 25 & 86 & 247 & 455 \\
\hline Myanmar & 981 & 1,636 & 43 & 73 & 240 & 815 & 1,264 & 2,524 \\
\hline Viet Nam & 1,518 & 2,530 & 168 & 286 & 939 & 3,189 & 2,625 & 6,005 \\
\hline Total & 27,780 & 46,301 & 4,075 & 6,924 & 22,734 & 77,223 & 54,589 & 130,448 \\
\hline
\end{tabular}

Lao PDR = Lao People's Democratic Republic, PRC = People's Republic of China.

Source: Asian Development Bank.

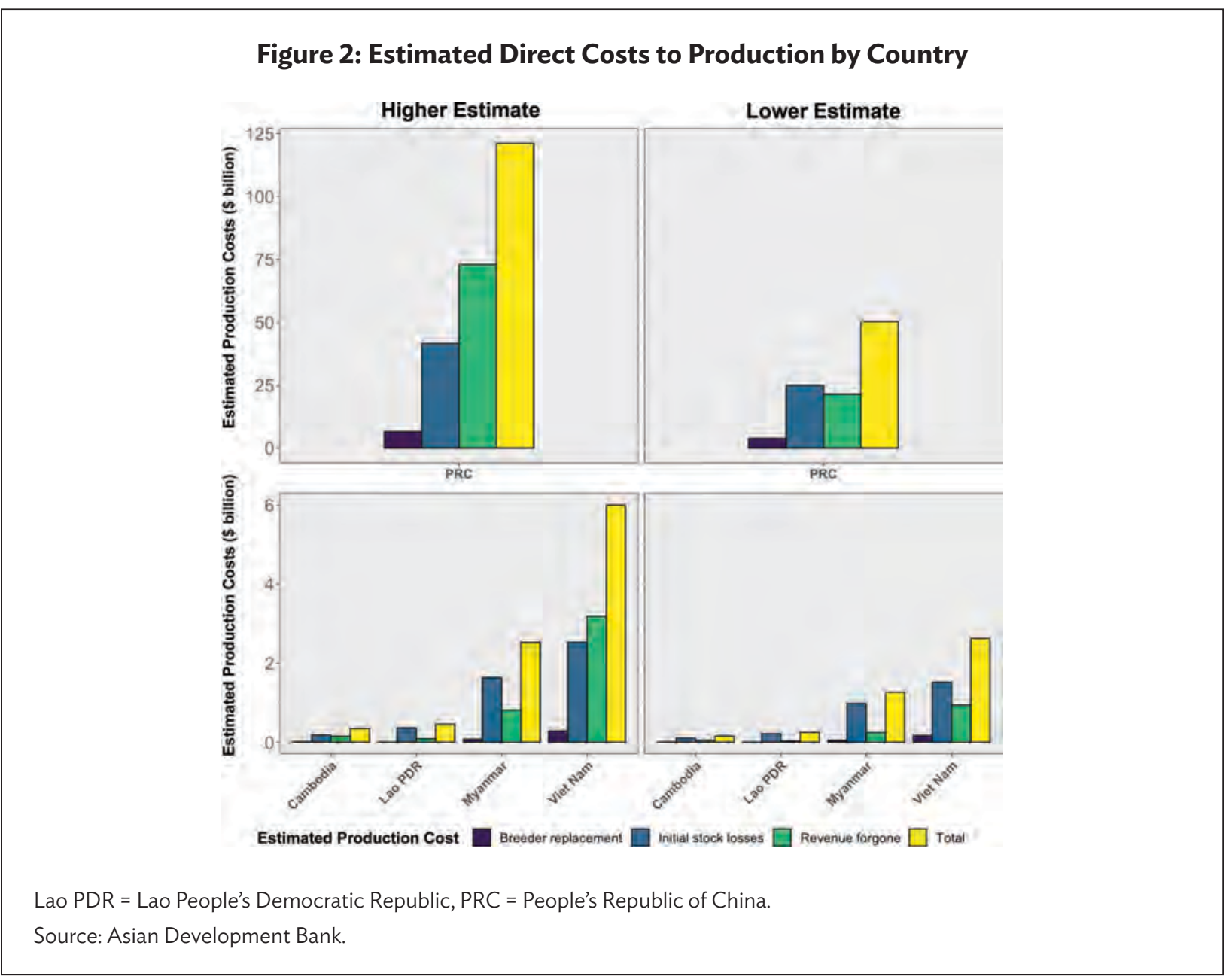

16. Analysis showed that the direct costs of the disease fall more heavily on smallholders in absolute terms due to the larger number of producers and pigs and the nature of typical smallholder systems (Figure 3 and Appendix 3). Costs are higher for smallholders on a per pig basis, which is exacerbated by the higher risks and costs of preventive measures in typical smallholder systems. 
Figure 3: Estimated Initial Costs of Deaths, Morbidity, and Culls of the African Swine Fever Outbreak by Production System and Country
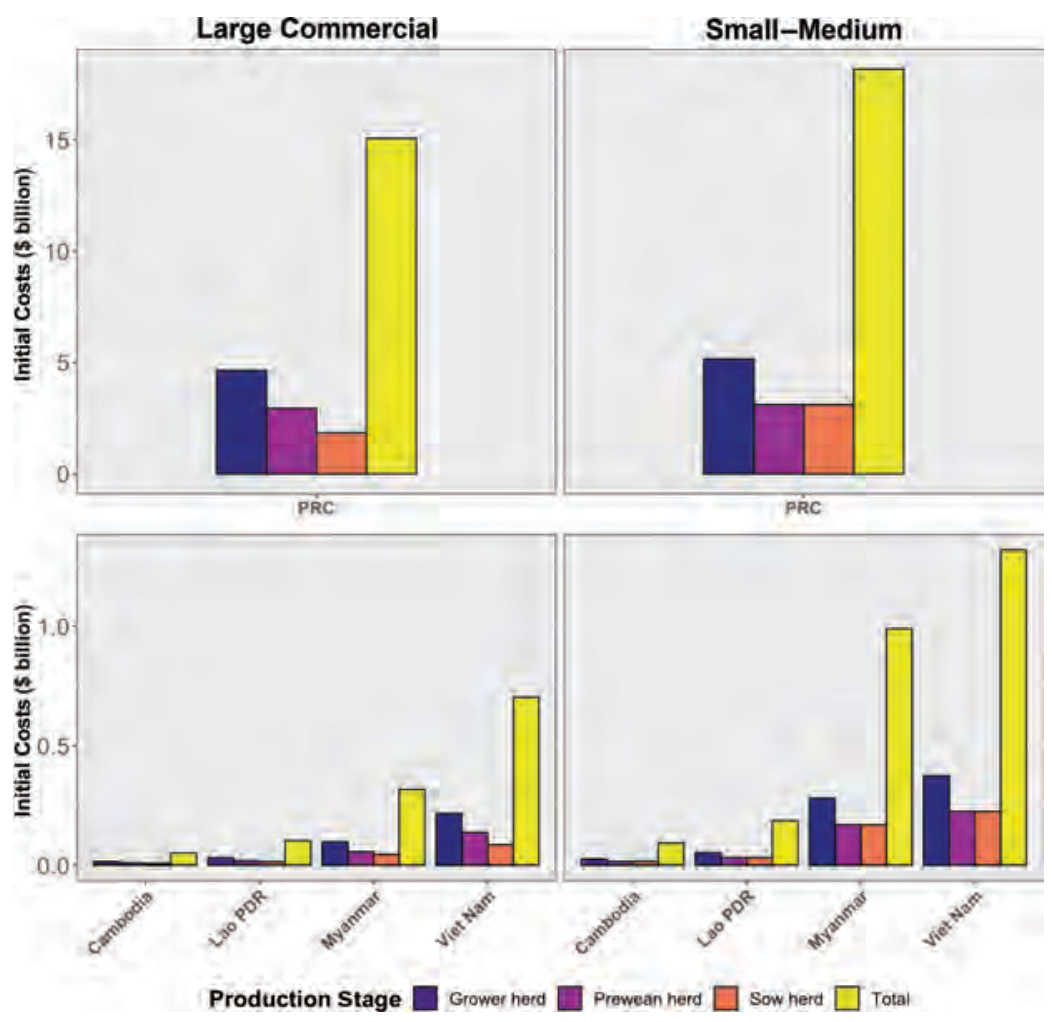

Lao PDR = Lao People's Democratic Republic, PRC = People's Republic of China.

Note: Average of the higher and lower estimates.

Source: Asian Development Bank.

17. Disaggregating cost estimates associated with ASF within the PRC provides an indication of the pig herd structure within the PRC and likely economic impacts of the spread of the disease throughout the PRC (Figure 4). The costs are approximate to the human population of each region. The risks in less populated areas, typically with lower density of pig production, are most likely lower, and these have implications on surveillance system design, increasing the likelihood of early detection and enacting effective disease prevention and control measures. 
Figure 4: Estimated Initial Costs of Deaths, Morbidity, and Culls of the African Swine Fever Outbreak in the People's Republic of China by Region and Production Stage

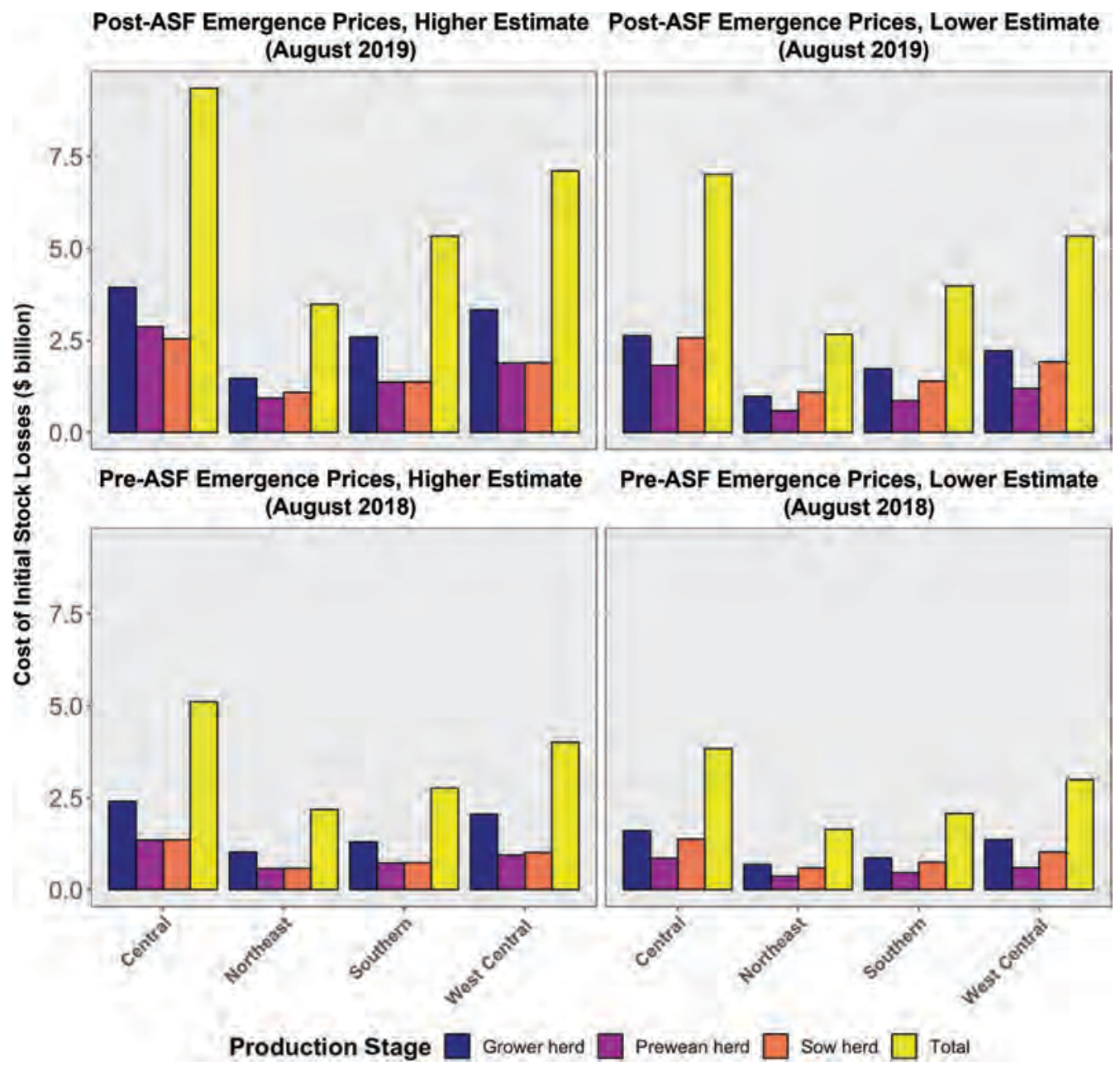

ASF = African swine fever.

Note: Higher estimates relate to an estimated infection rate of 0.5 while lower estimates are for an estimated infection rate 0 . The costs are calculated on regional average prices 1 year after the initial outbreak and before the disease emerged.

Source: Asian Development Bank; National Bureau of Statistics of China. 2018. National Data. http://data.stats.gov.cn/english/ easyquery.htm?cn=E0103\&f=912 (accessed 7 November 2019); D. Patton and H. Gu. 2019. Swine Fever Toll in China May Be Twice as High as Reported, Industry Insiders Say. Reuters. 30 June. https://www.reuters.com/article/us-china-swinefeverproduction-insight/swine-fever-toll-in-china-may-be-twice-as-high-as-reported-industry-insiders-say-idUSKCN1TV017.

18. Disaggregating the PRC pig production by province shows the disparity between provinces in terms of production volumes and the subsequent costs a disease such as ASF can have on provincial economies (Figure 5). The direct costs of stock losses and culling alone for Sichuan, the worst hit province due to its high levels of pig production and recent prevailing pig prices in the West Central region, range from $\$ 1.8$ billion to $\$ 3.8$ billion, unlike comparatively negligible losses in provinces like Qinghai, Ningxia Hui Autonomous Region, and Tibet Autonomous Region where pig production is limited and those producers that do operate are at lower risk due to the low pig density. 
Figure 5: Estimated Initial Costs of Deaths, Morbidity and Culls of the African Swine Fever Outbreak in the People's Republic of China by Province and Production Stage

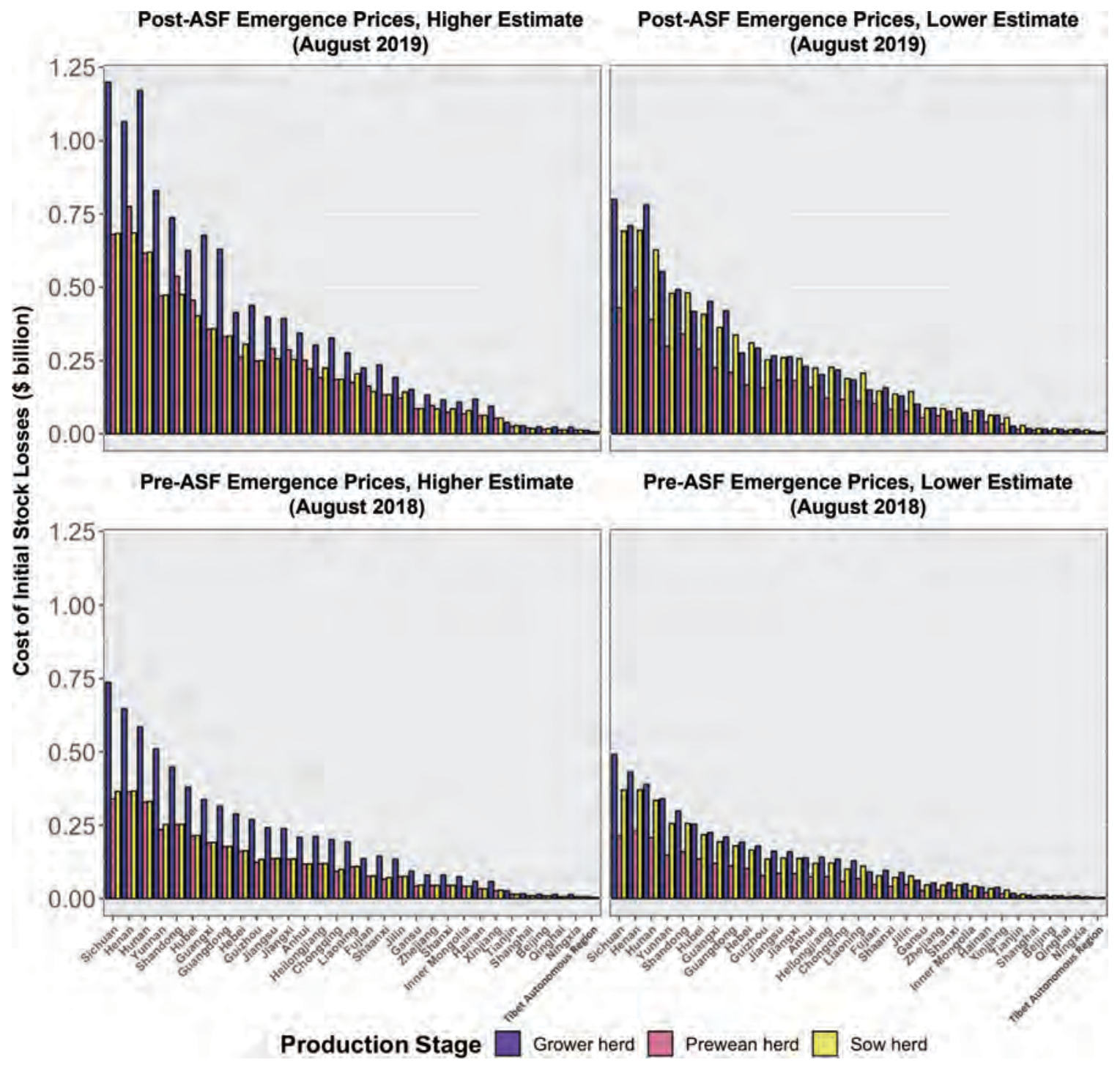

ASF = African swine fever

Note: Higher estimates relate to an estimated infection rate of 0.5 while lower estimates are for an estimated infection rate 0.3 , the costs are calculated on regional average prices 1 year after the initial outbreak and before the disease emerged.

Source: Asian Development Bank; National Bureau of Statistics of China. 2018. National Data. http://data.stats.gov.cn/english/ easyquery.htm?cn=E0103\&f=912 (accessed 7 November 2019); D. Patton. 2019. China Pig Farmer Profits Soar After Disease Wipes Out Third of Herd, Boosts Prices. Reuters. https://www.reuters.com/article/us-china-swinefever-profits-graphicidUSKCN1VA075. 
19. The costs of an outbreak are largely dependent on the nature of the pathogen and disease and the degree to which susceptible populations are exposed. Critical to minimizing the direct and indirect costs of an outbreak is early detection and control and/or stamping out. Liaoning Province, where the first outbreak was detected, had approximately 13 million pigs at the end of 2017 according to the National Bureau of Statistics of China (NBS no date). Simplistically, were the disease to have been limited to Liaoning Province (in effect shortening the epidemics progression spatially and temporally), the production costs of the disease and culling responses - including replacement of breeders and revenue forgone-would have been about $\$ 3.6$ billion- $\$ 5.2$ billion (Figure 6). If the outbreak had been controlled in the Northeast region of the PRC, the costs would have been about $\$ 18$ billion- $\$ 28$ billion. As the outbreak had spread through the PRC and to neighboring countries, the direct costs are likely to be at least $\$ 55$ billion- $\$ 130$ billion, without accounting for losses in Indonesia, which had since reported the disease, the Democratic People's Republic of Korea, the Philippines, the Republic of Korea, Timor-Leste, and other countries that are currently at risk. Stamping the disease out even earlier, which is conceivable with highly sensitive surveillance systems and effective responses, would potentially reduce the total costs to the economy, livelihoods, and food security to comparatively negligible levels.

\section{Figure 6: Estimated Direct Costs of Hypothetical African Swine Fever Control Scenarios}

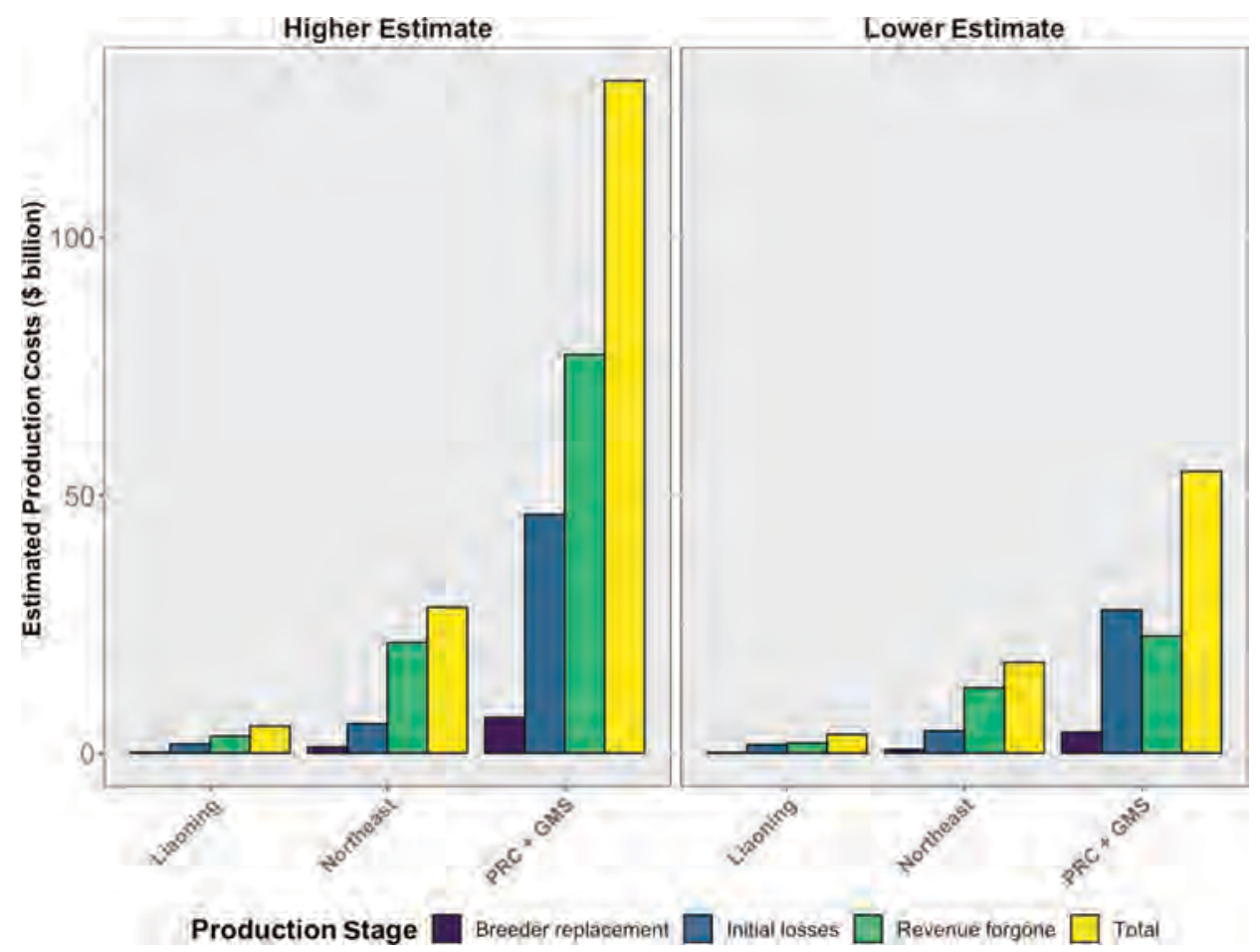

GMS = Greater Mekong Subregion, PRC = People's Republic of China.

Source: Asian Development Bank. 


\section{DISCUSSION}

20. Based on available data, the estimated direct production costs of ASF losses, replacement breeding stock, and revenue forgone in the PRC and neighboring countries are likely to be around $\$ 55$ billion- $\$ 130$ billion. This is realistic when one considers the costs estimated for other animal disease outbreaks and that approximately $50 \%$ of the world's pigs are raised in this region. As referenced previously, Knight-Jones and Rushton (2013) estimated that the production losses and vaccination costs of FMD were approximately $\$ 21$ billion in the early 2010 s. The FMD virus is a considerably more infectious agent but with far lower associated mortality rates and, importantly, effective vaccines and vaccination programs in place in many countries. When one considers the enormity of the PRC and broader east Asian pig industry and the scale of the outbreak, it is eminently plausible that the costs of production losses will run to between $\$ 50$ billion and $\$ 120$ billion for the PRC alone, and an additional $\$ 5$ billion- $\$ 10$ billion in the other GMS countries where outbreaks have occurred should the disease progress in a similar fashion to what occurred in the PRC.

21. In this analysis, the costs to the animal feed industry and other allied industries - such as animal and pork traders, slaughterers, animal health workers, pharmaceutical manufacturers, distributors, and so forth-were not considered. These costs will likely rise into billions of dollars as indicated by studies of the economic impacts of other diseases (Barratt et al. 2019 and World Bank 2010). The costs of responses beyond culls were also not accounted for, which are likewise substantial when one considers the scale and organization required and the logistical challenges of communicating and working closely with the industry and communities, detecting and monitoring the disease, establishing protection and surveillance zones, establishing and enforcing movement bans and market closures, the acts of culling and disposing of carcasses themselves, and the effective decontamination of farm premises.

22. The initial impact of losses through deaths is amplified by the costs of replacing lost animalsdiverting terminal lines to breeders and/or purchasing new breeder and/or weaner stock-thereby reducing the number of pigs reaching the market and causing a lag in supply while herds rebuild. This massive supply side shock has and will continue to drive up pig prices in the PRC and pork imports among other products in the short-term, thereby driving up pig and pork prices in the global market. According to data from the Ministry of Agriculture and Rural Affairs, Beek (2019) observed that reduced pork supply led to record high prices in early August 2019, reaching a national average of CNY35.12 per kg-a 57\% rise on prices in August 2018, prior to the outbreak (Ministry of Agriculture and Rural Affairs 2020). The authors note that the Ministry of Agriculture and Rural Affairs is projecting a $70 \%$ rise in the price of pork by the end of 2019 , which they consider a conservative estimate.

23. The ASF epidemic has demonstrated the enormous impact a catastrophic disease outbreak can have on supply of a critical foodstuff and prices for the products of animals that are directly affected as well as other foods and effects that ripple through other sectors. The knock-on effects on other foods, particularly the price of other meats in the PRC are already notable. Chicken, beef, and lamb prices have all risen in response to increased demand and high pork prices. High pork prices are affecting the broader consumer price index. Horton (2019) cited a Nomura International analysis that found that in May 2019 , the consumer price index for the PRC rose $2.5 \%$ year-over-year, which they largely attributed to rising pork prices. The index is expected to rise by more than $3 \%$ in the coming months. This will impact food security for many, especially given the large number of smallholder households who have lost an important income stream to the disease. Rural households are often net buyers of food. The impact of ASF on livelihoods also needs to be considered in relation to consumer price effects and how they impact food security. Further research into the costs and effects of ASF on livelihoods, particularly those of the poor and vulnerable, and consumer prices and food security are needed. 
24. The rise in the PRC consumer price index is complex and likely confounded but provides an indication of some of the substantial indirect costs of ASF on the PRC economy and other countries suffering from the disease, which will inevitably have repercussions in global markets. Calculating the indirect costs is extremely complex and beyond the scope of this paper. However, for such a critical disease it is reasonable to assume that the total indirect costs of the ASF epidemic to society will be greater than its direct costs (Barratt et al. 2019 and World Bank 2010).

25. The impacts of ASF on trade are already proving substantial. Undersupply of pork in the PRC is driving imports and pushing up international prices. The PRC is a massive importer of critical feed components such as soybeans. Diminished demand for feed components is likely to see prices in both the domestic and international market drop in the short term.

26. Pig trade in the region has fluctuated considerably in recent years with relatively volatile pork prices affected by global and local markets and policy changes; unlike the steady flow of cattle and buffalo into the PRC and Viet Nam from South Asia and the other GMS countries through informal routes. The long land borders in the PRC and GMS region present considerable challenges for containing diseases such as ASF and as has been seen with other TADs. The porous nature of borders, currently limited agreement on formal trade between countries, and laborious and costly nature of formal routes encourages the use of informal pathways. This hampers disease monitoring and risk management strategies thereby increasing the risk of disease spread. Formalizing trade will enable more effective risk monitoring and management. However, considerable investment in improved disease risk analysis and particularly risk management systems and demonstration of equivalence according to the World Trade Organization Sanitary and Phytosanitary Agreement are needed to enable formal trade between countries in the subregion.

27. The Asian Development Bank (ADB), among other development partners including the World Bank Group and various United Nations agencies, such as the FAO and Economic Commission for Europe, had invested substantial sums in sanitary and phytosanitary standards (SPS) capacity building and trade facilitation in the region over the past decade. In this regard, ADB initiatives have primarily targeted Cambodia, the Lao PDR, and Myanmar. The OIE, among others, through the South-East Asia and China Foot and Mouth Disease project and their work on policy, regulatory and legal frameworks in the region, have also contributed effectively to promoting alignment, benchmarking, harmonization and mutual recognition of equivalence in animal disease surveillance, preparedness, communication, and broader risk analysis within the region. The OIE also supports the operation of vaccine banks and vaccine distribution, particularly in relation to FMD, in Southeast Asia and globally. There is considerable potential to support and build on these and related initiatives in the region to develop effective, efficient, and robust animal health systems that increase the competitiveness of livestock value chains in a sustainable and inclusive manner.

28. These results demonstrate the enormous direct economic costs of ASF but fail to account for other effects on society and particularly the vast numbers of people in the PRC and neighboring countries whose livelihoods are directly or indirectly linked to pig and pork production and value chains. This includes input suppliers, live animal traders, slaughterers, meat workers, pork traders, and retailers.

29. In much of Asia, pig raising is a critical livelihood mechanism and form of insurance in times of need. It is notable that women are frequently heavily involved in small-scale livestock production and along local value chains. In a recent example, Smith et al. (2019) note the importance of pig raising in Timor-Leste. They describe the importance of pigs to households culturally and in terms of livelihoods and as fungible savings that may be deployed in response to economic shocks, often serving as a critical means of averting poverty in vulnerable households. In Timor-Leste, the large majority of pig raising is performed in backyard systems - the authors estimate the average herd size as under three 
head-in the PRC and GMS countries average herd sizes are considerably larger but the industry is numerically dominated by small-scale household run operations. However, although vast numbers of smallholders continue to raise pigs on a small scale, backyard or subsistence-type systems are largely confined to remote areas. Small, but relatively intensive fattening units and farrow to finish operations are commonplace. Large, frequently vertically integrated producers are increasingly important in terms of pig numbers, particularly in the PRC and Thailand, increasingly in Viet Nam, and to a lesser extent in Cambodia, the Lao PDR, and Myanmar.

30. The impact of ASF in absolute terms will be higher among smallholders due to the much larger number of farms and, at present, larger total pig numbers as shown by the estimated total initial costs of deaths and culls of the ASF outbreak (Figure 3). However, the burden of the disease is also falling disproportionately on small- and medium-scale producers on a per pig basis. Countless smaller pig raisers had been driven out of the business, removing a long-held source of income and form of savings, and threatening many with poverty or increasing their vulnerability to unexpected household expenses and other economic shocks.

31. It has generally been smallholders, unable to implement the biosecurity measures capable of mitigating the risk of ASF for practical and financial reasons and with no other means of protecting their herds (e.g., an effective vaccine), who have suffered catastrophic losses to the disease. This is particularly the case in the latter stages of the epidemic as commercial operations have invested heavily in improved biosecurity (Quilty 2019). The limited ability of smallholders to employ adequate biosecurity measures presents increased risks to neighboring herds where spatial separation is often low and preventive measures are impossible to apply in current housing. It has been estimated that introducing the biosecurity measures needed to prevent ASF incursion into large commercial operations in the PRC costs approximately $\$ 6$ per pig, while the costs for small farms may be as high as $\$ 30$ per pig (Quilty 2019).

32. Subsidies provided to commercial pig operations to temper the effects of lost production on pork supply, which is important for consumers and food security, are also likely to drive further concentration of industries (Quilty 2019). Already many small- and medium-scale farms have been put out of business and many more will inevitably follow as the disease and efforts to control the disease continue. There is already considerable evidence that this has already occurred and is continuing with many smallholders forced to seek alternative sources of income (Quilty 2019).

33. This may drive further urbanization of populations, a long-term trend associated with a variety of societal challenges (Jayanthakumaran 2016). The effects on availability of housing, food security, and the value of wage labor could have additional negative impacts on poverty and food security. The negative impacts of forced migration and additional pressure on urban areas may be felt in terms of poorer living conditions, reduced food security, increased urban poverty and vulnerability, and increased outbreaks of infectious diseases in the human population.

34. It is likely that the disease will remain endemic without the development of an effective vaccine; and even if a vaccine becomes available the disease will continue to circulate for some time as vaccine production and coverage ramps up. The large commercial industry are touting efforts to ensure high biosecurity standards in the wake of the initial outbreaks, reporting in a substantial decline among them while smaller operations continue to suffer (Quilty 2019).

35. Animal diseases can increase the negative effects of animal production on climate change and contribute to local environmental degradation. Livestock contribute to a majority of the estimated 10\%$12 \%$ of global greenhouse gas (GHG) emissions directly from agriculture (Reisinger and Clark, 2018). By reducing animal productivity through losses in production, animal disease, such as ASF, can increase net GHG emissions from livestock per kilogram consumed. Poorly managed waste from animal production 
and supply can also contaminate local natural resources such as waterways. However, investing in reducing the threat of disease, improving productivity, and better managing waste by using anaerobic biogas digestion, for example, in supply chains, can reduce this burden. Smallholder systems tend to have a lower environmental footprint than large intensive systems, therefore, improving smallholder competitiveness by reducing disease threats, improving productivity, and increasing market access can have environmental benefits. As this analysis has demonstrated, diseases such as ASF may further drive concentration of the industry, which may increase the environmental impacts of the animal production systems. There are also opportunities to promote adoption of greener production and transport technologies, such as renewables, that can reduce GHG emissions and increase natural resource efficiency.

36. Climate change also threatens productivity and, while complex, will likely increase the risk of TADs through effects on animal condition, vectors, and pathogen viability outside the host thereby reducing climate resilience, particularly among smallholders. Breed selection, investment in more resilient feed crops, and raising animals in buildings that improve rearing conditions by better managing heat and allowing application of more effective biosecurity measures can increase resilience to the effects of climate change, including reducing the risk of diseases such as ASF. Targeted public investment, technology transfer, and strengthened policy environments are needed to establish and promote further investment in greener livestock production, processing, and supply while increasing the resilience and long-term sustainability of animal production systems.

37. The ASF epidemic serves to highlight the massive economic and human costs that may be associated with widespread animal disease outbreaks. Of course, while ASF is critically important as has been shown by recent events, it is far from the only animal disease affecting livestock value chains, public health, and national economies (Appendix 4). The effects of classical swine fever, porcine reproductive and respiratory syndrome, FMD, and Newcastle disease, among many others have been highlighted elsewhere, including by FAO (2016). Admitting the difficulty in accurately assessing the impact of animal diseases in much of the world, FAO (2018) estimated the global cost burden of FMD in endemic regions to be more than $\$ 6.5$ billion per year with an additional $\$ 1.5$ billion per year due to outbreaks in previously FMD-free countries. Zoonotic diseases pose additional challenges and entail other direct and indirect costs such as human healthcare, lost labor, and reduced tourism and tourist spending. Examples include influenza viruses, brucellosis and foodborne pathogens such as Salmonella spp., pathogenic E. coli strains, and Campylobacter spp. The recent isolation of the zoonotic Rift Valley Fever virus from a patient in the PRC for the first time reveals, as Liu et al. (2017) note, the very serious threat of emerging diseases and/or the spread of diseases to regions previously free of such diseases. The ASF epidemic has served to highlight the need for further investment in disease prevention and controlrelated infrastructure, capacity building, and policy support, on animal production diseases but also to reduce the threats of zoonoses now and in the future.

\section{RECOMMENDATIONS}

\section{A. Strengthening Capacity to Prevent and Control Animal Diseases}

38. The substantial reductions in costs associated with early detection and stamping out of ASF, as with other diseases, are clear. Further investments in animal disease prevention, monitoring, risk communication, and outbreak and emergency response measures are urgently needed. The ASF epidemic has highlighted the need for regional approaches to addressing TADs and zoonoses. The 
increasing integration of animal supply chains and trade in the region emphasizes the need for regional approaches. Broad stakeholder engagement is essential to support and direct future investment.

39. Regional investment in animal health systems, production, value chains, and trade will contribute to all operational priorities ${ }^{5}$ of the ADB Strategy 2030 by strengthening rural livelihoods and food security, reducing public health risks, reducing GHG emissions and local environmental degradation, and increasing climate change resilience and fostering regional cooperation and integration (ADB 2018). This is directly aligned with the ADB Strategy for Regional Coordination, the Operational Plan of the Thematic Group on Agriculture and Natural Resources (ADB 2016a), the Operational Plan for Regional Integration and Cooperation, 2016-2020 (ADB 2016b), and the GMS Regional Investment Framework 2030 (ADB forthcoming).

\section{Infrastructure}

40. The quality and accessibility of animal disease risk management infrastructure varies widely in the region. Establishing quarantine facilities in line with international norms and upgrading sanitary and phytosanitary-related infrastructure and laboratory facilities and equipment is needed. This can support disease prevention, monitoring, control and/or containment and the establishment of disease control zones and/or the compartmentalization of industries, thereby better protecting domestic stakeholders and neighboring countries and increasing the ability to demonstrate system equivalence to current and potential export markets (OIE 2019b). Further investment in livestock value chain infrastructure, such as breeding facilities, fattening sites, aggregation points and live animal markets, slaughtering and processing facilities, modes of distribution, and wet markets can improve productivity, assist disease monitoring, and strengthen communication and coordination among actors. There are opportunities to attract private sector investment in much of this infrastructure through public-private partnerships or by enabling policy and regulatory environments. For example, formalizing trade can reduce risk and increase the attractiveness of investment in animal production-, health- and supply-related facilities.

\section{Capacity Building}

41. At present, surveillance capacity varies between countries. There is an urgent need to coordinate at a regional level and to build technical, leadership and management, and operational capacity in disease detection and monitoring, transparency, and risk management. Animal health services need strengthening. Regional disease monitoring and prevention systems, outbreak simulations, clearly defined communication channels, and response mechanisms can all serve to increase the likelihood of early detection and improve the effectiveness of prevention and response strategies. Incentives for disease reporting are needed to increase the likelihood of early detection and improve the efficiency and efficacy of responses. Stronger risk communication and compensation schemes, for example, need to be in place before outbreaks occur. Emergency risk communication systems within and between countries are needed to increase the effectiveness of prevention and control measures. Investment in the design and implementation of animal identification and traceability systems is needed. Building a cadre of inspectors, improving diagnostic capabilities, and increasing sampling in production and processing and of products can all serve to increase the likelihood of early detection and reduce the threat of pathogens important to both animal and human health.

5 These are: (i) addressing remaining poverty and reducing inequalities; (ii) accelerating progress in gender equality; (ii) tackling climate change, building climate and disaster resilience, and enhancing environmental sustainability; (iv) making cities more livable; (v) promoting rural development and food security; (vi) strengthening governance and institutional capacity; and (vii) fostering regional cooperation and integration. 


\section{Policy Support}

42. Regional policy support is needed to coordinate and strengthen policy, legislative, and regulatory environments to mutual benefit. Formalizing trade in live animals and animal products can improve disease surveillance but variable capacity currently inhibits recognition of equivalence. The current lack of formal pathways encourages the use of clandestine methods, which hamper monitoring and heighten the risk of disease spread among countries. Additional investment in livestock statistics and economic, epidemiological, and biological research relating to critical diseases and pathogens can provide evidence for improved policymaking. Further research on disease outbreak scenarios, critical pathogens, and disease transmission risk pathways and mechanisms and potential controls, such as vaccines, is needed.

43. More investments in aligning national SPS measures with international standards, capacity to implement SPS measures effectively, and strengthening of border services relating to pig and pork trade can reduce the risk of future emergence and spread of animal diseases (ADB 2019). Reviewing and adjusting legal provisions to support animal disease surveillance and import risk analysis, veterinary legislative reform, and the conduct of the Performance of Veterinary Services Pathway can support countries in achieving compliance with OIE standards, reduce the risk of disease, and improve the efficacy of outbreak responses.

\section{B. Investment Scenarios for Interventions}

\section{Business as Usual}

44. In a business-as-usual scenario, the private sector and governments will continue to invest in veterinary services and disease monitoring. However, it is unlikely that there will be considerable changes in capacity to detect disease outbreaks early and to then launch appropriate risk management responses to control and ideally stamp out the disease quickly and at minimum cost. The emergence and spread of ASF in Asia provide a stark example of current challenges facing animal disease monitoring and control. In this case, a well-known and characterized pathogen whose epidemiology and risk factors for spread have been well-described emerged and spread rapidly through the PRC despite long-term planning, preparations, and national investment in monitoring and control measures designed to contain the disease. Diseases such as FMD provide other examples of the challenges facing animal services, industries, and governments in effectively controlling infectious animal disease outbreaks in complex systems like animal production in East and Southeast Asia. In the case of less well-known or emerging diseases, early detection and control will likely be even more challenging and the risk of rapid spread and subsequent economic losses even greater.

\section{Strategic National and Regional Investment}

45. Strategic investment programs that support national and regional animal disease monitoring and outbreak preparedness and control can be highly effective in increasing surveillance capacity and preparedness. There are critical opportunities to support regional coordination and risk communication among governments and industries. Further investment in policy alignment and coordination can strengthen regional capabilities and encourage greater and safer trade within the region. Laboratory proficiency and test reliability remain variable within the region. A critical constraint to early detection of diseases is the low number of samples collected and processed through laboratories. Low sample throughput limits the likelihood of detecting diseases early, while also hampering laboratory technician capacity development and cost recovery. There is considerable need for greater field epidemiology capacity and inspection and monitoring of sentinel sites and supply chain bottlenecks, primarily live animal markets and slaughtering facilities. Many laboratories in the region also need further support in obtaining the international accreditations necessary to attract fees for service sample submissions. Supporting policy and regulatory changes and their enforcement that incentivize better practices and 
disease reporting can improve detection and reduce the spread of disease, thereby lowering costs and reducing the risks for stakeholders. Strategic investment in regional coordinating mechanisms, surveillance system capacity building, and risk communication capacity and systems can also rapidly improve preparedness and emergency responses that would benefit all.

\section{Comprehensive Investment}

46. Major investments in laboratories and critical value chain infrastructure may be considered. However, there has been considerable investment in animal health laboratory infrastructure and equipment in the region over the past 15-20 years, notably following the emergence of Severe Acute Respiratory Syndrome and highly pathogenic avian influenza H5N1. The main constraints to improved disease monitoring and control programs are generally capacity constraints and low sampling numbers. Variable technical proficiency reduces the likelihood of early detection and increases the risk of highly costly false positives that could severely impact industries if handled poorly. Although there is a considerable need to upgrade slaughtering and animal and product marketing facilities, the high value of industries and rapidly growing demand indicate that private investment financing can be leveraged. Inspection and monitoring capacity is a public good; it is also essential for the industry. However, private funding for monitoring and regulation is unlikely to be forthcoming and has the potential to create conflicts of interest.

\section{CONCLUSIONS}

47. This study demonstrates the high costs associated with the devastating ASF epidemic affecting Asian pigs, smallholders, industries, governments, and consumers. The effects of the disease on the larger economy, livelihoods, food security, human health security, and the environment are substantial. There is an urgent need for regional investment in animal health systems to reduce the likelihood and costs of ASF and future animal diseases and zoonoses. This study used a simplistic approach to calculating the direct costs of ASF to present initial estimates of the direct costs of the disease to date. Further analysis employing more sophisticated epidemiological and econometric modeling is needed to better inform national and regional decision making and direct investments in animal and zoonotic disease prevention, monitoring, and control. 


\section{APPENDIX 1: Methods Employed to Estimate Direct Cost of African Swine Fever}

48. To estimate the direct production costs of African swine fever (ASF) in the People's Republic of China (PRC) and the neighboring countries of the Greater Mekong Subregion (GMS), which subsequently reported the disease, the study estimated the costs of losses to the disease (mortality and morbidity) and culling, the costs of lost breeders during the projected replenishment phase due to pigs being retained (or purchased) for breeding purposes, and the revenue forgone in the form of lost marketable pigs due to the time to replace lost gilts and sows.

49. To calculate initial production costs of the disease (deaths, morbidity, and culls) the study used a simple deterministic approach. Although stochastic models were considered incorporating greater accounting for uncertainty, this risked masking deficiency in the data and the number and scope of assumptions. As the intention of this analysis was to provide a starting point for more detailed and sophisticated economic assessment, a simple deterministic approach with suitable declaration of assumptions and uncertainties is believed to provide the least risk of misrepresentation.

50. The calculations employed in determining the initial losses associated with the disease were:

where:

$$
\begin{gathered}
D_{M t}=P I M_{t} \\
D_{M b}=P I M_{b} \\
D_{c}=D_{M t} V_{M t}+D_{M b} V_{M b}
\end{gathered}
$$

$$
\begin{aligned}
D_{M t}= & \text { disease associated mortality (due to disease and culling) } \\
D_{M b}= & \text { disease associated morbidity } \\
D_{C}= & \text { costs of disease } \\
P= & \text { population at risk (naïve population therefore, with no vaccination, the national pig herd) } \\
I= & \text { infection rate/attack rate (proportion of the pig population that becomes infected and/ } \\
& \text { or are culled during disease response efforts) } \\
M_{t}= & \text { mortality rate (proportion of infected that die) } \\
M_{\mathrm{b}}= & \text { morbidity rate (proportion of infected that fall ill/show clinical signs, which reduce value, } \\
& \text { but recover) } \\
V_{M t}= & \text { value of loss to mortality } \\
V_{M b}= & \text { value of loss to morbidity }
\end{aligned}
$$

51. In conducting the calculations, data was grouped by various attributes: country; production system (intensive commercial and smallholder); and production stage (sows, preweaners or suckling pigs, and weaner-grower-finishers). The number of animals by production system (commercial or smallholder) was determined using the available literature updated following consultations with experts and to reflect recent developments to national industries in subsequent years (Deka et al. 2014). The estimated fraction of the national pig herds by production stage (sow, prewean, weaner-grower-finisher) was estimated on the basis of general estimates from smallholder and commercial systems in the region and expert consultations (Smith et al. 2019). Pigs that died were assumed to lose $100 \%$ of their value while morbidity was set at $75 \%$ loss of value. 
52. This study used the Livestock Development Planning System, version 2 (LDPS-2) tool (Lalonde and Sukigara 1997) to calculate the number of gilts and young boars that would need to be retained to restock the sow and boar populations required in smallholder and intensive commercial systems nationally to supply estimated national demand levels prior to the outbreak of ASF. This tool is also deterministic. It allows the differential parameterization of livestock off-take models for different types of production system and in response to disease and no-disease scenarios. The tool was used to broadly assess costs of ASF at national level on the basis of demand prior to the outbreak and losses (to the disease or culling) of 30\%-50\% based on current reports and using live pig prices as reported prior to the outbreak (thereby providing a potentially conservative estimate of the costs of forgone revenue).

53. The value of these animals was estimated on the basis of average per kilogram liveweight prices recorded in 2017 in the PRC (the year prior to the outbreak). Prices in the PRC were used as these figures could not be reliably obtained for other countries given the high levels of informal trade and pig price volatility in the region.

54. Finally, the study considered the revenue forgone during stock replenishment through lost terminal piglets that would have been marketed as finished slaughter hogs. The study assumed that an average of two parturitions (approximately 1 year) would be lost per lost sow (based on the age profile of typical sow herds, years of productivity, and so forth). The study examined typical production figures in the two systems (commercial and smallholder) based on figures obtained from academic literature in the region and internationally. This study determined the average number of parturitions, litter sizes, number of pigs per sow per year, and normal mortality rates for terminal stock for the different systems and calculated the number of market weight pigs that failed to reach the market during restocking. The same liveweight prices were then used to approximate the revenue foregone, estimating that average profits per head ranged from $15 \%$ to $50 \%$ before and after the ASF outbreak in the PRC.

55. Price data. Pig prices in the PRC from 2017 were used in regional calculations (Table A1.1). Pig and pork prices have fluctuated considerably over the past 10 years due to complex factors including policy changes and global feed prices. Moreover, due to the difference in scale of the PRC herd, and subsequent losses, and neighboring country herds, the effect of minor differences between countries is negligible, especially when considering the preliminary nature of this analysis and the assumptions made. In analyses of economic impacts within the PRC, regional price estimates from Patton (2019) were used (Table A1.2).

Table A1.1: Pig Price Data Used in Cross-country Analyses

\begin{tabular}{ccccc}
\hline System & Production Stage & Live Weight $^{\mathrm{a}}(\mathrm{kg})$ & Price/kg $(\$)$ & Price/head $(\$)$ \\
\hline Small-medium & Prewean & 15 & 7.14 & 107.14 \\
Small-medium & Grower & 70 & 2.86 & 200.00 \\
Small-medium & Sow & 150 & 2.14 & 321.43 \\
Commercial & Prewean & 20 & 7.14 & 142.86 \\
Commercial & Grower & 90 & 2.86 & 257.14 \\
Commercial & Sow & 200 & 2.14 & 428.57 \\
\hline
\end{tabular}

$\mathrm{kg}=$ kilogram .

a Estimated average live weight for the system and stage.

Sources: Food and Agriculture Organization Corporate Statistical Database. http://www.fao.org/faostat/en/\#home (accessed 9 January); Nga, N. et al. 2015. Household Pork Consumption Behavior in Vietnam: Implications for Pro-Smallholder Pig Value Chain Upgrading. International Livestock Research Institute (ILRI). Nairobi. Presented at the Conference on International Research on Food Security, Natural Resource Management and Rural Development. 16-18 September. Berlin, Germany; United States Department of Agriculture (USDA). 2016. China - People's Republic of: Livestock and Products Annual. GAIN Report Number: CH 16043. Global Agricultural Information Network (GAIN). Washington D.C.: USDA Foreign Agricultural Service; USDA. 2019. Livestock and Poultry: World Markets and Trade. Foreign Agricultural Service. Washington D.C.; A. Zhang. 2019. One Year on From the First ASF Outbreak, Where is China's Pork Industry Heading? The Pig Site. https://www.thepigsite.com/articles/one-year-on-from-the-first-asf-outbreakwhere-is-chinas-pork-industry-heading. 


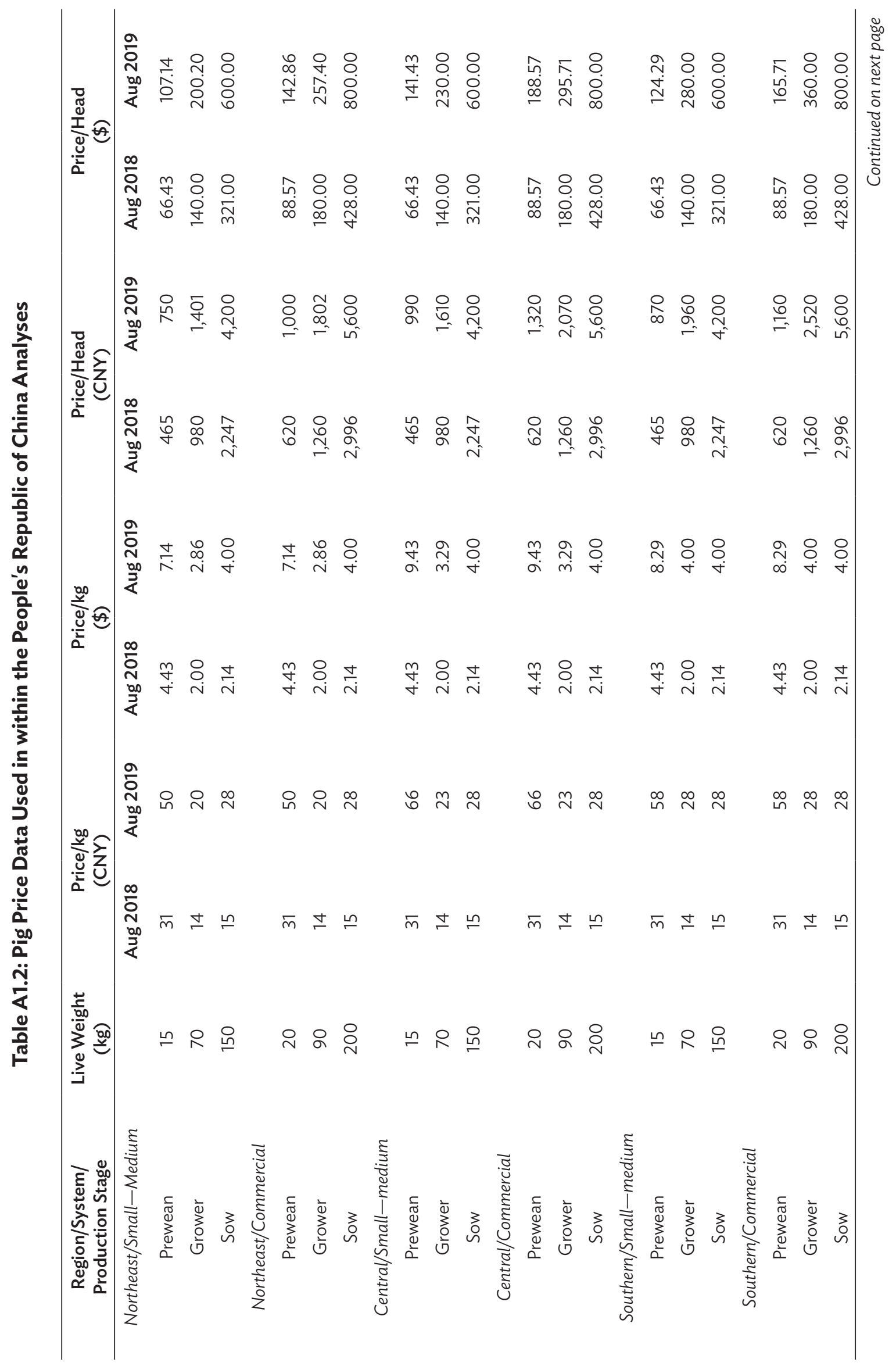




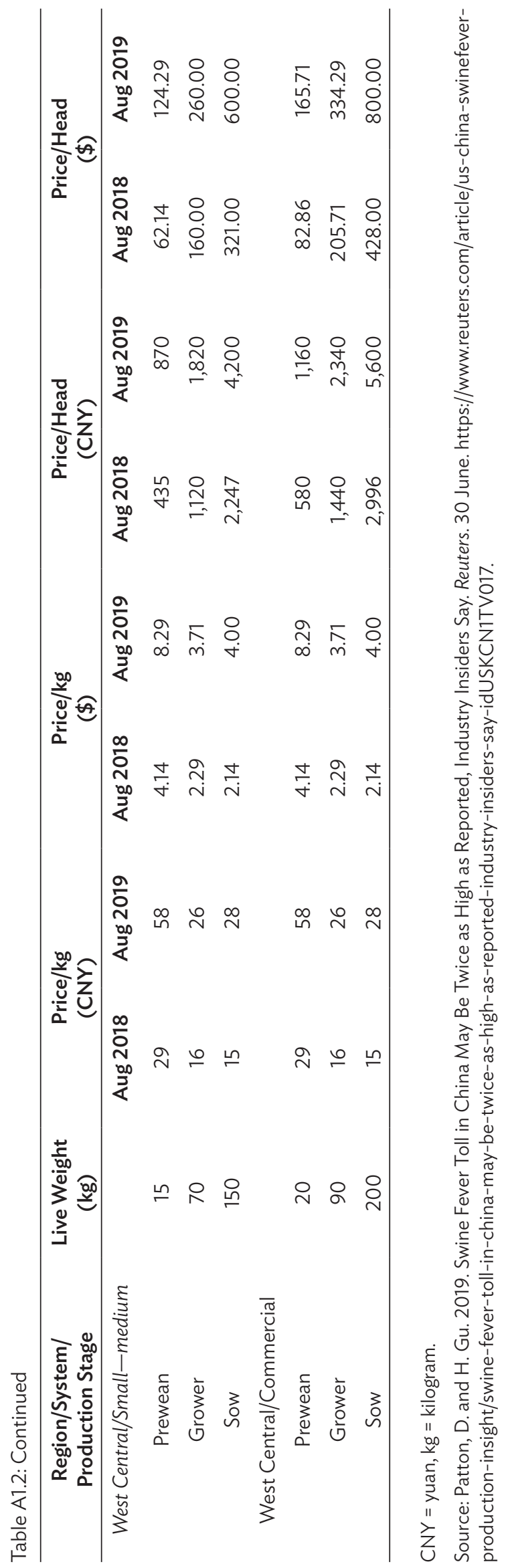




\section{APPENDIX 2: Parameters Used in the Livestock Development Planning System, Version 2 Herd Dynamic Model}

56. The Food and Agriculture Organization of the United Nations (1997) Livestock Development Planning System, version 2 (LDPS-2) herd dynamic model was used to estimate the number of replacement breeding animals required by the production sector to return production to pre-African swine fever outbreak levels to meet the demand for domestic pork products. Table A2 provides the value ranges used to set parameters in the LDPS-2 model.

Table A2: Production Parameters Used in the Food and Agriculture Organization of the United Nations Livestock Development Planning System, Version 2 Herd Dynamic Model

\begin{tabular}{|c|c|}
\hline Parameter & Range \\
\hline Meat production demand $(t)$ & $41,148-55,000,000$ \\
\hline Fraction of target to be met by intensive system ${ }^{a}$ & $0.1-0.5$ \\
\hline Distribution loss ${ }^{a}$ & - \\
\hline Female breeder mortality rate ${ }^{a}$ & $0.2-0.5$ \\
\hline Male breeder mortality rate ${ }^{a}$ & $0.2-0.5$ \\
\hline Female replacement mortality rate $e^{a}$ & $0.01-0.50$ \\
\hline Male replacement mortality rate ${ }^{a}$ & $0.01-0.50$ \\
\hline Slaughter stock mortality rate ${ }^{a}$ & $0.01-0.50$ \\
\hline Year(s) in breeding herd ${ }^{a}$ & $3.0-5.0$ \\
\hline Year(s) in replacement herd ${ }^{a}$ & $0.5-1.0$ \\
\hline Year(s) to slaughter for slaughter stock ${ }^{a}$ & $0.5-1.0$ \\
\hline Average live weight, breeder female ${ }^{a}(t)$ & $0.2-0.25$ \\
\hline Average live weight, breeder male $(t)$ & $0.2-0.25$ \\
\hline Average live weight, slaughter stock ${ }^{a}(t)$ & $0.08-0.10$ \\
\hline Dressing percentage (\%) & $70-75$ \\
\hline Litters per sow per year ${ }^{a}$ & $1.8-2.2$ \\
\hline Size of litter ${ }^{a}$ (head) & $9-12$ \\
\hline Females per male breeder ${ }^{a}$ (head) & 25 \\
\hline Distribution losses, traditional systems ${ }^{b}$ & - \\
\hline Female breeder mortality rate $e^{b}$ & $0.2-0.5$ \\
\hline Male breeder mortality rate $e^{b}$ & $0.2-0.5$ \\
\hline Female replacement mortality rate $e^{b}$ & $0.01-0.50$ \\
\hline Male replacement mortality rate $e^{b}$ & $0.01-0.50$ \\
\hline Slaughter stock mortality rate $e^{b}$ & $0.01-0.50$ \\
\hline Year(s) in breeding herd ${ }^{b}$ & $4-6$ \\
\hline Year(s) in replacement herd ${ }^{b}$ & $0.8-1.2$ \\
\hline Years to slaughter for slaughter stock & $0.7-0.9$ \\
\hline Average live weight, breeder female $(t)$ & $0.15-0.20$ \\
\hline Average live weight, breeder male $(t)$ & $0.17-0.23$ \\
\hline Average live weight, slaughter stock $(t)$ & $0.06-0.90$ \\
\hline
\end{tabular}


Table A2: Continued

\begin{tabular}{lcc}
\hline & Parameter & Range \\
\hline Litters per sow per year $^{b}$ & $1.5-2.0$ \\
\hline Size of litter ${ }^{b}$ (head) & $8-11$ \\
\hline Females per male breeder $^{b}$ (head) & $12.5-20.0$ \\
\hline Fraction of fallen animal eaten & NA \\
\hline
\end{tabular}

- = no data available.

$\mathrm{t}=$ metric ton .

a For intensive production systems.

${ }^{b}$ For traditional production systems.

Source: ADB. 


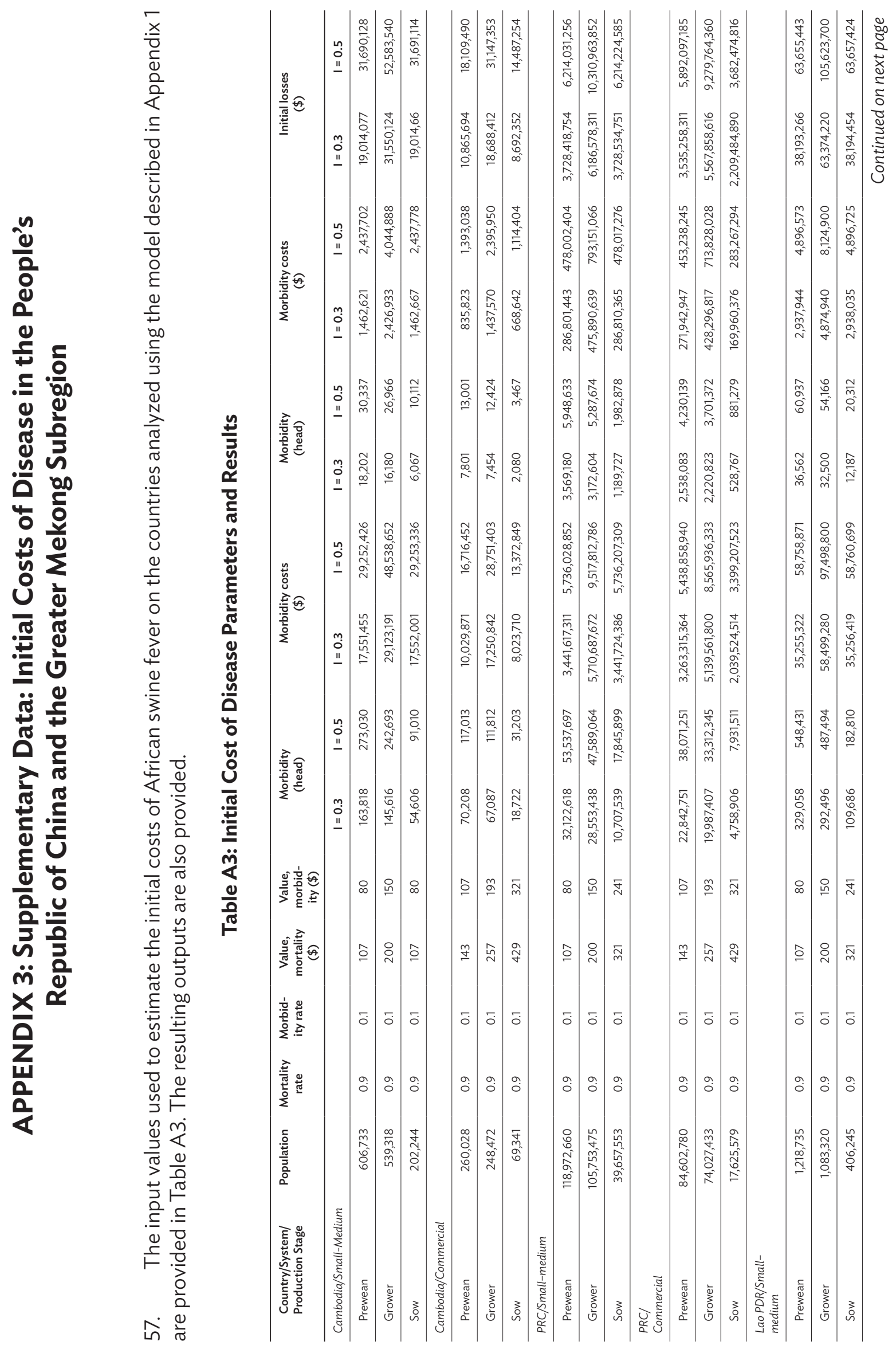




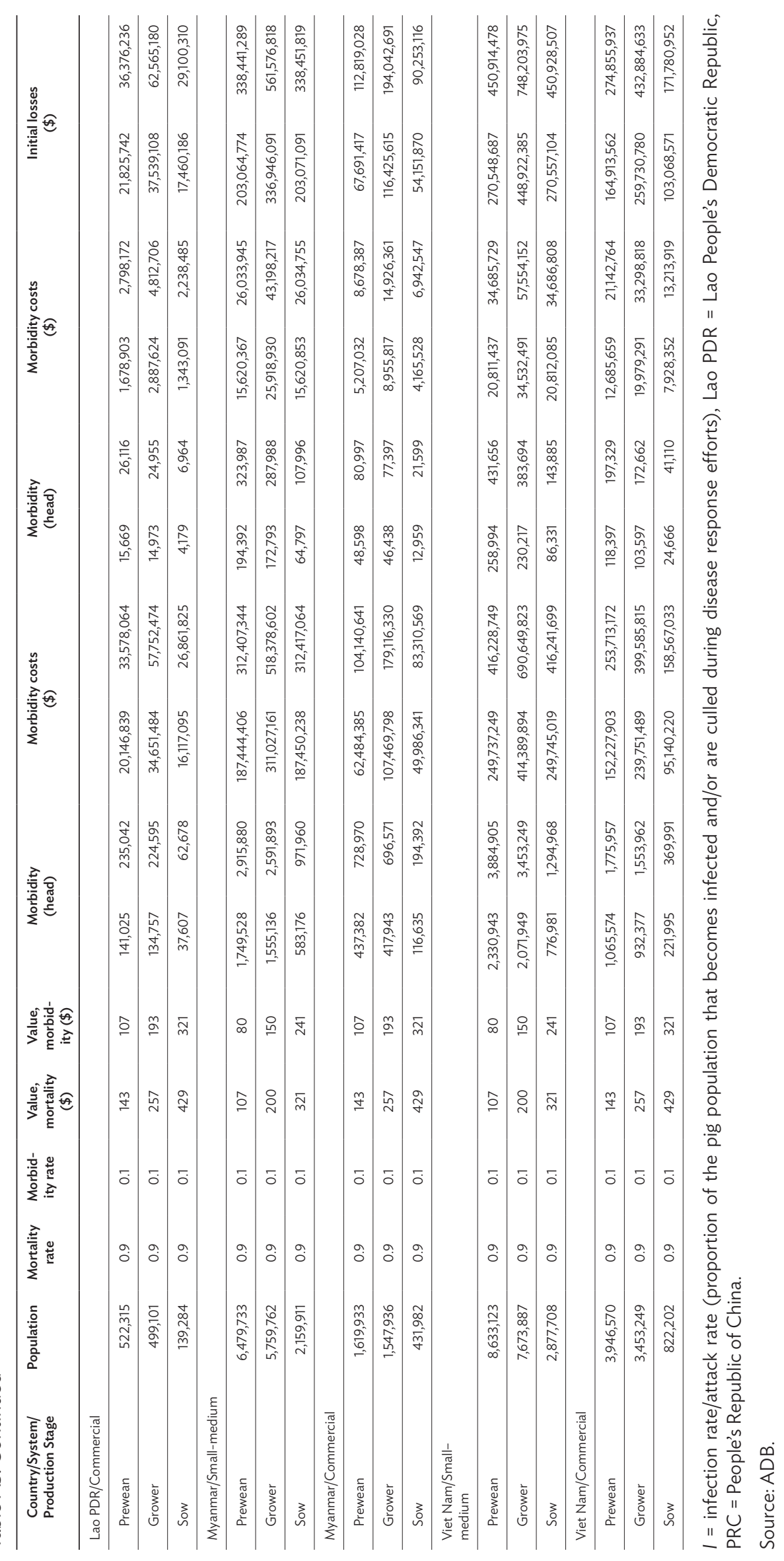




\section{APPENDIX 4: Critical Transboundary Animal Diseases, Foodborne Pathogens, and Non-Foodborne Zoonoses}

58. This paper considers the 2018 outbreak of African swine fever in East Asia specifically, however, as referred to in the discussion section of the paper, there are numerous other diseases that impact animal producers and, at times, human health directly in the form of zoonoses. Table A4 lists some of the most important hazards to animal and human health associated with animal production in Asia, particularly.

Table A4: Examples of Terrestrial Animal Production Associated Hazards in the People's Republic of China and the Greater Mekong Subregion

\begin{tabular}{ll}
\hline \multicolumn{1}{c}{ Hazard Category } & \multicolumn{1}{c}{ Potential Hazards } \\
\hline $\begin{array}{l}\text { Transboundary Animal } \\
\text { Diseases }\end{array}$ & $\begin{array}{l}\text { Endemic or frequent outbreaks. Foot-and-mouth disease, classical swine fever, porcine } \\
\text { reproductive and respiratory syndrome, highly pathogenic avian influenza viruses (HPAI) } \\
\text { (e.g., H5N1, H7N9, H1N1), Newcastle disease } \\
\text { Emerging or high risk. African swine fever, other HPAl and influenza viruses, pest de petit } \\
\text { ruminants }\end{array}$ \\
\hline Foodborne Pathogens & $\begin{array}{l}\text { Salmonella spp, enterotoxigenic E. coli, shiga-toxin producing E. coli, Campylobacter spp., } \\
\text { Toxoplasma gondii, Trichinella spiralis, Taenia solium, various other parasites including other } \\
\text { nematodes, cestodes and trematodes (flukes, Fasciola spp., etc.) }\end{array}$ \\
\hline $\begin{array}{l}\text { Non-foodborne } \\
\text { Zoonoses }\end{array}$ & $\begin{array}{l}\text { HPAl, Mycobacterium bovis (bovine tuberculosis), Bacillus anthracis (anthrax), Leptospira spp. } \\
\text { (leptospirosis), Coxiella burnetti (Q fever), Brucella spp. (brucellosis), Streptococcus suis }\end{array}$ \\
\hline Chemical Hazards & $\begin{array}{l}\text { Veterinary drug residues. Primarily antimicrobial residues and coccidiostats and other } \\
\text { parasiticides, growth hormones, and other growth promoters }\end{array}$ \\
\hline
\end{tabular}

Source: ADB. 


\section{REFERENCES}

Asian Development Bank. 2016a. Operation Plan for Agriculture and Natural Resources: Promoting Sustainable Food Security in Asia and the Pacific in 2015-2020. Manila. https://www.adb.org/documents/ operational-plan-agriculture-and-natural-resources-2015-2020.

2016b. Operational Plan for Regional Cooperation and Integration, 2016-2020: Promoting Connectivity, Competitiveness, Regional Public Goods, and Collective Action for Asia and the Pacific. Manila. https://www.adb.org/documents/operational-plan-regional-cooperation-integration-2016-2020.

2018. Strategy 2030: Achieving a Prosperous, Inclusive, Resilient, and Sustainable Asia and the Pacific. Manila. https://www.adb.org/documents/strategy-2030-prosperous-inclusive-resilientsustainable-asia-pacific.

2019. Modernizing Sanitary and Phytosanitary Measures in CAREC: An Assessment and the Way Forward. Manila. https://www.adb.org/publications/modernizing-sanitary-phytosanitary-measurescarec.

Forthcoming. Greater Mekong Subregion Regional Investment Framework 2030. Manila.

Barratt, A. S. et al. 2019. Framework for Estimating Indirect Costs in Animal Health Using Time Series Analysis. Frontiers in Veterinary Science. 6. p. 190.

Beek, V. T. 2019. ASF China: Pork Prices Soar As Future Effects Become Clear. Pig Progress. https:/www.pigprogress.net/Health/Articles/2019/9/ASF-China-Pork-prices-soar-as-future-effectsbecome-clear-467811E/.

Chenais, E. et al. 2019. Epidemiological Considerations on African swine fever in Europe 2014-2018. Porcine Health Management. 5 (6). 9 January. https://porcinehealthmanagement.biomedcentral.com/ articles/10.1186/s40813-018-0109-2.

Deka, R. P. et al. 2014. Sharing lessons of Smallholders' Pig System in South Asia and Southeast Asia: A Review. International Livestock Research Institute (ILRI). Nairobi. https://pdfs.semanticscholar.org/f30e/ d1523feee575fb2cecb35e25357555a10cd0.pdf.

Food and Agriculture Organization of the United Nations (FAO). 2016. Economic Analysis of Animal Diseases. FAO Animal Production and Health Guidelines. No. 18. Rome. http://www.fao.org/3/a-i5512e.pdf.

2018. The Global Foot and Mouth Disease Control Strategy. Rome. http://www.fao.org/3/ i9857en/19857EN.PDF.

2019. ASF Situation in Asia Update. http://www.fao.org/ag/againfo/programmes/en/empres/

ASF/Situation_update.html.

Food and Agriculture Organization Corporate Statistical Database. http://www.fao.org/faostat/ en/\#home (accessed 9 January 2020). 
Gale, J., H. Dormido, and A. Leung. 2019. African Swine Fever Is Spreading Fast and Eliminating It Will Take Decades. Bloomberg. https://www.bloomberg.com/graphics/2019-eliminating-african-swinefever/.

Gallardo, C. et al. 2009. Recombinant Antigen Targets for Serodiagnosis of African Swine Fever. Clinical and Vaccine Immunology. 16 (7). pp. 1012-1020. https://cvi.asm.org/content/16/7/1012.

Gallardo, C. et al. 2017. Experimental Infection of Domestic Pigs with African Swine Fever Virus Lithuania 2014 Genotype II Field Isolate. Transboundary and Emerging Diseases. 64 (1). pp. 300-304.

Ge, S. et al. 2018. Molecular Characterization of African Swine Fever Virus, China, 2018. Emerging Infectious Diseases. 24 (11). pp. 2131-2133.

Halasa, T. et al. 2018. Modeling the Effects of Duration and Size of the Control Zones on the Consequences of a Hypothetical African Swine Fever Epidemic in Denmark. Frontiers in Veterinary Science. 5. p. 49. https://www.frontiersin.org/articles/10.3389/fvets.2018.00049/full.

Havelaar, A. H. et al. 2015. World Health Organization Global Estimates and Regional Comparisons of the Burden of Foodborne Disease in 2010. PLoS Medicine. 12 (12). 3 December. https://www.ncbi.nlm. nih.gov/pmc/articles/PMC4668832/.

Horton, C. 2019. China's African Swine Fever Outbreak Ripples Across Asia: As Higher Pork Prices Spark Inflation, Many See Long-Term Economic Impact. Nikkei Asian Review. 1 June. https://asia.nikkei. com/Business/Agriculture/China-s-African-swine-fever-outbreak-ripples-across-Asia.

Jayanthakumaran, K. 2016. Industrialization and Challenges in Asia. New York: Springer.

Jones, K. E. et al. 2008. Global Trends in Emerging Infectious Diseases. Nature. 451 (7181), pp. 990-993. 21 February. https://www.nature.com/articles/nature06536.

Knight-Jones, T. J. D. and J. Rushton. 2013. The Economic Impacts of Foot and Mouth Disease - What Are They, How Big Are They and Where Do They Occur? Preventive Veterinary Medicine. 112 (3-4). pp. 161-173. https://www.ncbi.nlm.nih.gov/pmc/articles/PMC3989032/.

Lalonde, L. G. and T. Sukigara. 1997. LDPS-2 User's Guide Rome: FAO.

Li, X. and K. Tian. 2018. African Swine Fever in China. The Veterinary Record. 183 (9). p. 300.

Liu, J. et al. 2017. The First Imported Case of Rift Valley Fever in China Reveals a Genetic Reassortment of Different Viral Lineages. Emerging Microbes and Infections. 6 (1). pp. 1-7.

Mackenzie, D. 2019. A Quarter of All Pigs Have Died This Year due to African Swine Fever. New Scientist. 5 November. https://www.newscientist.com/article/2222501-a-quarter-of-all-pigs-havedied-this-year-due-to-african-swine-fever/.

MARA. 2020. Data and Statistics. Ministry of Agriculture and Rural Affairs of the People's Republic of China. http://english.moa.gov.cn/datastatistics/(accessed on 7 November 2019).

McCracken, C., C. Pan, and J. Sherrard. 2019. Rising African Swine Fever Losses to Lift All Protein Boats. Rabobank RaboResearch. April. https://research.rabobank.com/far/en/sectors/animal-protein/risingafrican-swine-fever-losses-to-lift-all-protein.html. 
National Bureau of Statistics of China. 2018. National Data. http://data.stats.gov.cn/english/easyquery. htm? cn=E0103\&f=912 (accessed 7 November 2019).

Nga, N. et al. 2015. Household Pork Consumption Behavior in Vietnam: Implications for ProSmallholder Pig Value Chain Upgrading. International Livestock Research Institute (ILRI). Nairobi. Presented at: Conference on International Research on Food Security, Natural Resource Management and Rural Development. 16-18 September, 2015. Berlin, Germany.

National Pork Producers Council. Pork Facts. https://nppc.org/pork-facts/.

O’Neill, J. I. M. 2014. Antimicrobial Resistance: Tackling a Crisis for the Health and Wealth of Nations. Review on Antimicrobial Resistance. 20. pp. 1-16.

OIE (World Organisation for Animal Health). 2019a. African Swine Fever. Paris: OIE. 2019b. Terrestrial Animal Health Code. Paris: OIE.

Patton, D. 2019. China Pig Farmer Profits Soar After Disease Wipes Out Third of Herd, Boosts Prices. https://www.reuters.com/article/us-china-swinefever-profits-graphic/china-pig-farmer-profits-soarafter-disease-wipes-out-third-of-herd-boosts-prices-idUSKCN1VA075.

Patton, D. and H. Gu. 2019. Swine Fever Toll in China May Be Twice as High as Reported, Industry Insiders Say. Reuters. 30 June. https://www.reuters.com/article/us-china-swinefever-productioninsight/swine-fever-toll-in-china-may-be-twice-as-high-as-reported-industry-insiders-sayidUSKCN1TV017.

Phipps, J. 2019. Why ASF Outbreak Estimates in China Are Hogwash. Farm Journal's Pork. 7 October. https://www.porkbusiness.com/article/john-phipps-why-asf-outbreak-estimates-china-are-hogwash.

Quilty, S. 2019. China Reaches a Crossroad in Rebuilding its Hog Industry. Global AgriTrends. https:// www.globalagritrends.com/blogs/analysis_china_reaches_a_crossroad_in_rebuilding_its_hog_ industry.

R Core Team. 2019. R: A Language and Environment for Statistical Computing. Vienna: R Foundation for Statistical Computing.

Reisinger, A. and H. Clark. 2018. How Much Do Direct Livestock Emissions Actually Contribute to Global Warming? Global Change Biology 24 (4). pp. 1749-1761.

Rushton, J. et al. 2018. Initiation of Global Burden of Animal Diseases Programme. The Lancet 392 (10147). pp. 538-540.

Smith, D. et al. 2019. Counting the Cost: The Potential Impact of African Swine Fever on Smallholders in Timor-Leste. One Health, 100109. 8. December.

United States Department of Agriculture (USDA). 2016. China - People's Republic of: Livestock and Products Annual. GAIN Report Number: CH 16043. Global Agricultural Information Network (GAIN). Washington D.C.: USDA Foreign Agricultural Service.

2019. Livestock and Poultry: World Markets and Trade. Foreign Agricultural Service.

Washington D.C. 
Van Boeckel, T. P. et al. 2015. Global Trends in Antimicrobial Use in Food Animals. Proceedings of the National Academy of Sciences. 112 (18). pp. 5649-5654.

World Health Organization. Health Topics. Zoonoses. http://origin.who.int/topics/zoonoses/en/.

TDR. Diseases and Topics. Vectors. https://www.who.int/tdr/diseases-topics/vectors/en/. 2006. Neglected Zoonotic Diseases. https://www.who.int/neglected_diseases/diseases/ zoonoses/en/.

World Bank. 2010. People, Pathogens and Our Planet, Volume 1: Towards a One Health Approach for Controlling Zoonotic Diseases. Web Report. 1. pp. 1-74. http://documents.worldbank.org/curated/ en/214701468338937565/Volume-one-towards-a-one-health-approach-for-controlling-zoonoticdiseases.

2017. From Panic and Neglect to Investing in Health Security: Financing Pandemic Preparedness at a National Level. International Working Group on Financing Preparedness. Washington, D.C.: World Bank Group.

World Grain. 2019. ASF Outbreak Reaches Beyond China. 3 October. https://www.world-grain.com/ articles/12689-asf-outbreak-reaches-beyond-china.

Zhang, A. 2019. One Year on From the First ASF Outbreak, Where is China's Pork Industry Heading? The Pig Site. https://thepigsite.com/articles/one-year-on-from-the-first-asf-outbreak-where-is-chinaspork-industry-heading.

Zhou, X. et al. 2018. Emergence of African Swine Fever in China, 2018. Transboundary and Emerging Diseases. 65 (6). pp. 1482-1484. 


\section{Evaluating Losses Associated with African Swine Fever in the People's Republic of China and Neighboring Countries}

This paper aims to assist policymakers in assessing the scale of the impact of African swine fever (ASF) on the People's Republic of China (PRC) and Southeast Asia. The results of the study indicate that ASF's direct costs on the PRC - which produces about half of the world's pigs - and neighboring countries could be as much as $\$ 130$ billion. Much of the burden is falling disproportionately on smallholders, threatening increases in poverty, vulnerability, and food insecurity. ASF has driven up the prices of pork and other food supplies, and it also has had substantial effects on human health, trade, climate change resilience, and local environments.

\section{About the Asian Development Bank}

ADB is committed to achieving a prosperous, inclusive, resilient, and sustainable Asia and the Pacific, while sustaining its efforts to eradicate extreme poverty. Established in 1966, it is owned by 68 members -49 from the region. Its main instruments for helping its developing member countries are policy dialogue, loans, equity investments, guarantees, grants, and technical assistance. 